\title{
Terasy Wetliny w Bieszczadach (Karpaty Wschodnie) - próba porównania ich hipsometrii, budowy i wieku z doliną górnego Sanu
}

\author{
Terraces of the Wetlina River in the Bieszczady Mountains, Eastern Carpathians: an \\ attempt at comparison of their hypsometry, structure and age with the valley of the Upper \\ San River
}

\begin{abstract}
Józef Kukulak
Instytut Geografi, Uniwersytet Pedagogiczny im. Komisji Edukacji Narodowejw Krakowie; e-mail: jkukulak@up.krakow.pl
\end{abstract}

Zarys treści: W górskiej dolinie rzeki Wetlina (Bieszczady Wysokie) znajduje się schodowy system sześciu teras rzecznych (T1-T6). Wszystkie terasy mają wysokie cokoły skalne i żwirowe pokrywy akumulacyjne. Przetrwały w tej dolinie także residua żwirów staroglacjalnych. Dowiązanie wieku teras do reperu datowanych szczątków drewna i torfu na jednej z teras Wetliny (Ralska-Jasiewiczowa 1969, 1980) pozwala na wydzielenie w badanej dolinie 2-3 teras niskich (dennych) holoceńskich i 3 teras wysokich (zboczowych) plejstoceńskich. Z hipsometrycznej korelacji teras Wetliny z terasami pobliskiego Sanu wynika, że w dolinie Wetliny terasy są znacznie wyższe i mają bardziej zaburzone profile podłużne. Lokalne zmiany wysokości teras Wetliny i miąższości ich pokryw akumulacyjnych nie wykazują korelacji ze wskaźnikiem krętości koryta rzeki. Są one uwarunkowane względnie dużą podatnością skał strefy przeddukielskiej i ich silną fragmentaryzacją tektoniczną na erozyjne pogłębianie koryta rzeki.

Słowa kluczowe: terasy rzeczne, pokrywy żwirowe, Bieszczady, Karpaty Wschodnie

\begin{abstract}
A stair-case system of six river terraces (T1-T6) with accumulation covers and bedrock toe occurs in the valley of the Wetlina River. Residual deposits of earlier glaciations are also present in this valley. Correlation of the age of the terraces with the dated organic material (wood and peat) on one of the terraces (Ralska-Jasiewiczowa 1969, 1980) allows delimitation of the levels of Pleistocene terraces: $2-3$ within the valley floor (low terraces) and 3 within the slopes (high terraces). Hypsometric correlation of the terraces of the Wetlina and the nearby San River indicates that the terraces of the Wetlina are considerably higher and their longitudinal profiles are more distorted. Local variability in the elevation of the Wetlina terraces and in the thickness of their alluvial covers is not correlated with channel sinuosity and may have resulted from the complex tectonic structure and relatively low resistance of the bedrock of the Fore-Dukla Zone to the erosion of the river bed.
\end{abstract}

Key words: river terraces, gravelly covers, Bieszczady Mountains, Outer Carpathians

\section{Wprowadzenie}

W dolinach rzek karpackich pospolitymi formami fluwialnymi są skalno-osadowe terasy. Tworzą one schodową sekwencję spłaszczeń dna dolin (terasy denne) i dolnych partii zboczy (terasy zboczowe). Przyjmuje się, że kolejno niższe stopnie w tej sekwencji są chronologicznie młodsze, wskazuje na to m.in. lepszy stopień ich zachowania. Tak jest również w pobliskich dolinach dorzecza górnego Sanu (Starkel 1965) i Strwiąża (Henkiel 1962, Gębica i in. 2008) oraz w innych dolinach beskidzkich:
Wisłoka (Magiera 1991), Wisłoki (Sobiecki 2000), Ropy (Wójcik 1997, 2003), Dunajca (Baumgart-Kotarba 1978, 1983, Zuchiewicz 1984), Kamienicy i Ochotnicy (Olszak 2011), Koszarawy (Wójcik 1988) i Soły (Ziętara 1972). Zwykle terasy z biegiem dolin zyskują większą rozległość (oprócz odcinków przełomowych), a często również wysokość. W górę dolin wnikają najdalej terasy najniższe.

Powstanie schodowego systemu teras nawiązuje do cyklicznego w czwartorzędzie rozwoju den dolin karpackich, powodowanego zarówno przez zmiany klimatu, jak i neotektoniczne wypiętrzanie obszaru (Klimaszew- 
ski 1948, 1967, Starkel 1965, 2003, Zuchiewicz 1992). W każdym z cykli zaznaczała się w dnach dolin faza wyraźnej erozji (w okresach interglacjalnych) i faza dominującej agradacji osadów (w okresach glacjalnych). W przejściowych okresach cykli przeważało erozyjne poszerzanie koryt (Dziewański, Starkel 1962, Starkel i in. 1999, Vanderberge 2002, Starkel 1994, 2003), jakkolwiek jest możliwe, że erozja boczna mogła postępować lokalnie także w okresach glacjalnych (Hancock, Anderson 2002). Jest także możliwe, że pokrywy żwirowe na niektórych terasach pochodzą z okresów interglacjalnych. W tych okresach na osadach starorzecznych wysokich teras Sanu i Solinki mogły się gromadzić gliny stokowe i tworzyć osady organiczne (Dziewański, Starkel 1962, Gerlach i in. 1997). Dominacja procesów erozji lub agradacji były zależne od wielkości przepływów rzek i dostawy materiału stokowego do ich koryt (Starkel i in. 1999, 2007, Bogaart, van Balen 2000). Cykliczne zmiany procesów fluwialnych postępowały w warunkach nierównego tempa wypiętrzania obszaru, czego przejawem są dziś różne lokalnie wysokości skalnych cokołów w jednowiekowych poziomach teras. Wypiętrzanie Karpat w czwartorzędzie uznaje się za stałe (Dziewański, Starkel, 1962) lub okresowo nasilone (Baumgart-Kotarba 1978, Zuchiewicz 1984, 1987, 1992, Wójcik 1988).

W sekwencji teras karpackich obok wielu podobieństw, dotyczących np. takiej samej ilości poziomów teras, stopnia ich zachowania, obecności skalnych cokołów, występują także lokalne różnice, które dotyczą m.in. wysokości teras i budowy różnowiekowych pokryw aluwialnych. Nierówności w podłużnych profilach teras tłumaczy się m.in. obecnością progów w korycie lub oddziaływaniem dopływów rzek (Pękala 1966), lub też różnicą wielkości pionowego wypiętrzenia części dorzeczy (m.in. Baumgart-Kotarba 1978, Wójcik 1988, Zuchiewicz 1992).

Przykładem doliny wyróżniającej się wśród dolin sąsiednich wyższymi terasami jest górny odcinek doliny Wetliny w Bieszczadach Wysokich. Większość teras w tej dolinie jest wyższa od teras równowiekowych w dużo większej, sąsiedniej dolinie Sanu. W porównaniu z doliną Sanu zwraca uwagę również wyraźniej zachowany system teras zboczowych, bardziej gruboklastyczny rodzaj osadów rzecznych i lokalnie duża ich miąższość w terasach średnich. Celem niniejszego artykułu jest prezentacją teras rzecznych w dolinie Wetliny i próba wyjaśnienia przyczyny ich dużej wysokości względnej. Ta cecha teras wzdłuż Wetliny zdaje się nie wynikać ani z dawnego reżimu rzeki i wielkości jej przepływów, ani z nasilonej aktywności ruchów pionowych tej części Bieszczadów. Można przyjąć założenie, że jej wytworzeniu sprzyjały warunki litologiczne i tektoniczne miejscowego podłoża.

\section{Obszar badań}

Do badań wybrano dolinę Wetliny w Bieszczadach Wysokich (polska część Karpat Wschodnich), usytuowaną w obniżeniu śródbieszczadzkim. Wetlina płynie ku NW i odwadnia NE skłony pasma granicznego ze Słowacją (Czoło 1159 m n.p.m., Paportna 1198 m n.p.m., Jawornik 1021 m n.p.m.) oraz SW stoki pasma połonin (Połonina Wetlińska 1255 m n.p.m., Smerek 1222 m n.p.m.). Jest ona prawym ramieniem Solinki - lewostronnego dopływu Sanu. Ma gęstą sieć bocznych dopływów, wciętych poprzecznie w oba przyległe pasma górskie (ryc. 1). Jest ona doliną głęboko wciętą $(550-600 \mathrm{~m}) \mathrm{w}$ utwory fliszowe strefy przeddukielskiej (jednostki śląskiej), przed czołem nasunięcia jednostki dukielskiej. Jej górny i środkowy odcinek (ok. $12 \mathrm{~km}$ ) jest subsekwentny w stosunku do struktur podłoża, natomiast dolny odcinek (ok.10 km) jest przełomowy przez pasmo połonin. Tam Wetlina, po połączeniu się z Solinką, wpływa do zbiornika solińskiego.

Badaniami objęto górny fragment doliny rzeki Wetlina (o łącznej długości ok. 20,5 km) złożony z trzech odcinków (ryc. 1). Dwa z nich obejmują doliny źródłowych cieków Wetliny: Górnej Solinki (A - ok. 9,5 km długości) i Wetlinki (B - ok. 4,5 km), a trzeci jest odcinkiem doliny Wetliny $(\mathrm{C}-\mathrm{ok} .6 \mathrm{~km})$ poniżej połączenia wymienionych wyżej cieków. Wyraźnie ukształtowany system teras ciągnie się nie tylko wzdłuż koryta samej Wetliny, ale także w górę obu jej źródłowych cieków. Górna Solinka i Wetlinka łączą się w Wetlinę na południowo-wschodnim skraju wsi o tej samej nazwie. Od tego miejsca system teras $\mathrm{w}$ dolinie jest najlepiej zachowany i kompletny (sześć stopni). Badanie teras na odcinku C zakończono na potoku Smerek (dopływ Wetliny) w miejscowości Smerek.

Przedział wysokości, w którym występują terasy w trzech odcinkach doliny (A, B, C), wynosi $600-800$ m n.p.m. Podłużny profil koryt Górnej Solinki, Wetlinki

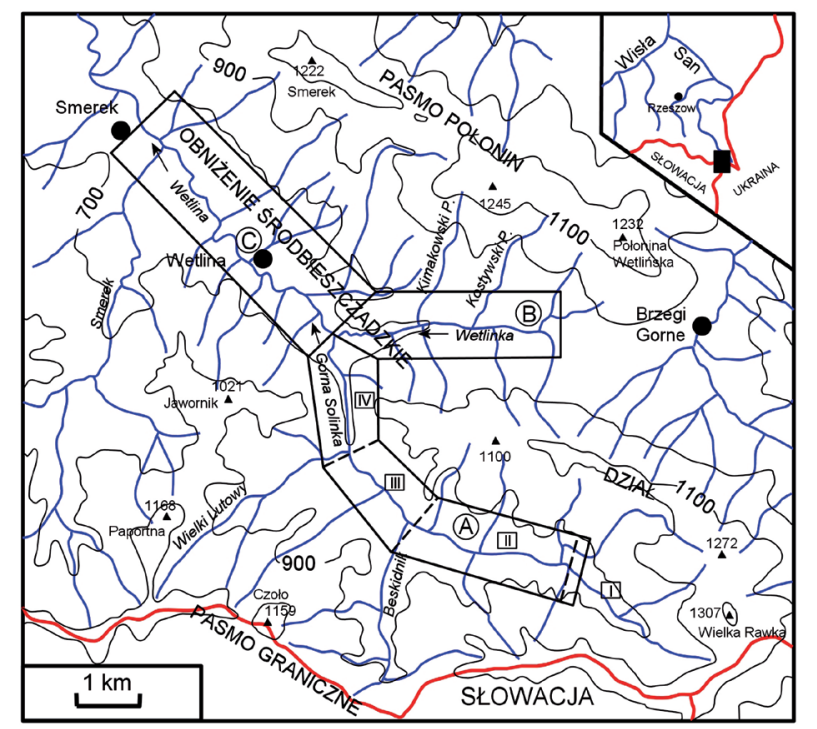

Ryc. 1. Położenie badanego fragmentu doliny Wetliny w Bieszczadach: A - odcinek Górnej Solinki, B - odcinek Wetlinki, C - odcinek Wetliny. Wzdłuż Górnej Solinki zaznaczono cztery jej części (I, II, III, IV) opisane w tekście

Fig. 1. Location of the studied reach of the Wetlina valley in the Bieszczady Mountains: A - Upper Solinka reach, B - Wetlinka reach, $\mathrm{C}-$ Wetlina reach. The four sections of the Upper Solinka described in the text are marked I, II, III and IV 
i Wetliny nie jest wyrównany. W ich korytach występują progi skalne, a spadek rzek waha się od 23,8\% (Wetlinka), 21\% (Górna Solinka) do 8,3\% (Wetlina). Dolina Wetliny na odcinku $\mathrm{C}$ jest płaskodenna, ma sterasowane dno o zmiennej lokalnie szerokości (80-300 m) oraz łagodne, schodowe zbocza, które wyraźną granicą oddzielają się od bardzo stromych stoków przyległych grzbietów. Oś doliny na tym odcinku ma przebieg prostolinijny, ale koryto jest kręte, miejscami nawet meandrowe.

\section{Metody badań}

Na każdym z trzech odcinków doliny wykonano w terenie szczegółowe kartowanie geomorfologiczne i geologiczne wszystkich teras, dokumentując ich rozprzestrzenienie na mapie w skali 1:10 000. Pomierzono względne wysokości teras nad korytem rzek, oprofilowano budowę ich pokryw akumulacyjnych w zakresie miąższości i składu mechanicznego aluwiów. Na terasach z aluwiami przykrytymi glinami zboczowymi zmierzono miąższość tych glin. W terasach podcinanych przez Wetlinę pomierzono również wysokości ich skalnych cokołów i miąższość pokryw akumulacyjnych. Wiek teras oszacowano w oparciu o datowanie torfu na jednej ze średnich teras Wetliny w Smereku (Ralska-Jasiewiczowa 1969, 1980) oraz analogię z piętrowym systemem teras pobliskiego Sanu i Wołosatki (Pękala 1966, 1997, Tokarski 1975, Haczewski i in. 1998, 2001, 2007, Kukulak 2004). Przestrzenną rozciągłość różnowiekowych teras Wetliny przedstawiono na mapie, ich względne wysokości zestawiono w tabeli, a pozostałe cechy teras (litologię osadów, wysokości cokołów skalnych) pokazano na przekrojach poprzecznych doliny i profilach szczegółowych. Profile te wykonano na podstawie map topograficznych i pomiarów $\mathrm{w}$ terenie.

\section{Terasy Wetliny w literaturze}

Terasy Wetliny nie były dotąd szczegółowo prezentowane w literaturze tak geomorfologicznej, jak i geologicz- nej. W dużym uogólnieniu pod względem przestrzennym i wiekowym są one przedstawione na mapie geologicznej Polski 1:200 000, arkusz Łupków (Ślączka, Żytko 1978). Stopnie teras i budowę wewnętrzną terasy średniej udokumentowano lokalnie w Smereku - w sąsiedztwie badanego torfowiska Smerek (Ralska-Jasiewiczowa 1969, 1980, Kaszowski, Ralska-Jasiewiczowa 1972). O schodowym ułożeniu teras Wetliny sygnalizowano również przy analizie strukturalnej rzeźby podnóża Połoniny Wetlińskiej (Górka, Kuśmierek 1973) i rzeźbie odcinków przełomowych Wetliny i Solinki przez pasmo połonin (Kuśmierek, Magiera 1993, Kuśmierek 2005). Trwałość starych pokryw żwirowych stwierdzono na wysokich poziomach doliny Wetliny (Malarz 2001, 2007), Solinki i Sanu (Dziewański, Starkel 1962, Starkel 1965). Kompleksowe opracowanie teras, ale tylko w źródłowym fragmencie dorzecza Wetliny, zawiera przygotowana do publikacji Szczegółowa Mapa Geologiczna Polski 1:50 000, arkusz Ustrzyki Górne wraz z jej tekstowymi objaśnieniami (Haczewski i in. 2001). Układ teras Wetliny można jednak porównywać morfologicznie i korelować wiekowo nie tylko z doliną Wołosatki i górnym biegiem Sanu (literatura cytowana wyżej), ale także z niższym, bieszczadzkim biegiem doliny Sanu (Dziewański, Starkel 1961, 1962, Starkel 1965, 1966, 1995, 2003, Pękala 1973) i górnego Strwiąża (Henkiel 1962, Gębica i in. 2008). Bliskość wymienionych dolin pozwala zakładać, że terasy w ich obrębie formowały się w tych samych cyklach glacjalnointerglacjalnych i w podobnych ogólnie warunkach środowiska, zatem mają one wiele cech podobnych.

\section{Wyniki badań teras Wetliny}

\section{Ilość teras, ich hipsometria i rozmieszczenie}

$\mathrm{Na}$ badanym odcinku doliny Wetliny występują terasy skalno-osadowe w układzie schodowym. Ich zespół składa się z sześciu stopni (T1-T6) o różnym rozwinięciu powierzchni i stopniu zachowania. Najlepiej zachowane są terasy niskie (T6-T4), będące stopniami dna doliny (terasy denne), terasy wyższe (T3-T1) są głęboko rozcię-

Tabela 1. Wysokość teras T1-T6 (m) w dolinie Wetliny i ich prawdopodobny wiek

Table 1. The height of river terraces in individual sections of the valley Wetlina and their probable age

\begin{tabular}{|c|c|c|c|c|c|c|}
\hline \multirow{2}{*}{ Odcinek } & \multicolumn{6}{|c|}{ Numeracja teras / wiek } \\
\hline & $\mathrm{T} 1 / \mathrm{P} 1$ & $\mathrm{~T} 2 / \mathrm{P} 2$ & $\mathrm{~T} 3 / \mathrm{P} 3$ & T4/PG* & $\mathrm{T} 5 / \mathrm{H} 1$ & $\mathrm{~T} 6 / \mathrm{H} 2$ \\
\hline Górna Solinka & - & $16-30$ & $11-15$ & $\begin{array}{c}6-10 \\
(8-10)\end{array}$ & $\begin{array}{c}2-4 \\
(4-6)\end{array}$ & $\begin{array}{l}0,5-1,0 \\
1,0-2,0\end{array}$ \\
\hline Wetlinka & - & $>20 ?$ & $10-15$ & $\begin{array}{c}6-9 \\
(5-9)\end{array}$ & $\begin{array}{c}3-5 \\
(4-6)\end{array}$ & $\begin{array}{l}0,5-1,0 \\
1,0-2.0\end{array}$ \\
\hline Wetlina & $35-50$ & $2-30$ & $12-15$ & $7-10^{*}$ & $4-6$ & $\begin{array}{l}1,0-2,0 \\
2,0-3,0\end{array}$ \\
\hline
\end{tabular}

P1 - zlodowacenie południowopolskie (Sanu); P2 - zlodowacenie środkowopolskie; P3 - zlodowacenie północnopolskie (Wisły); PG - późny vistulian/ wczesny holocen; H1 - starszy holocen; H2 - młodszy holocen; w nawiasach podano występujące lokalnie wysokości teras

* - wiek terasy wg Ralska-Jasiewiczowa 1969, 1980

P1 - South-Polish Glaciation; P2 - Middle-Polish Glaciation, P3 - Vistulian Glaciation, PG - early Holocene / Late Glacial (Vistulian), H1 - older Holocene, $\mathrm{H} 2$ - younger Holocene; local terrace elevation is indicated in brackets

* - terrace age after Ralska-Jasiewiczowa $(1969,1980)$ 


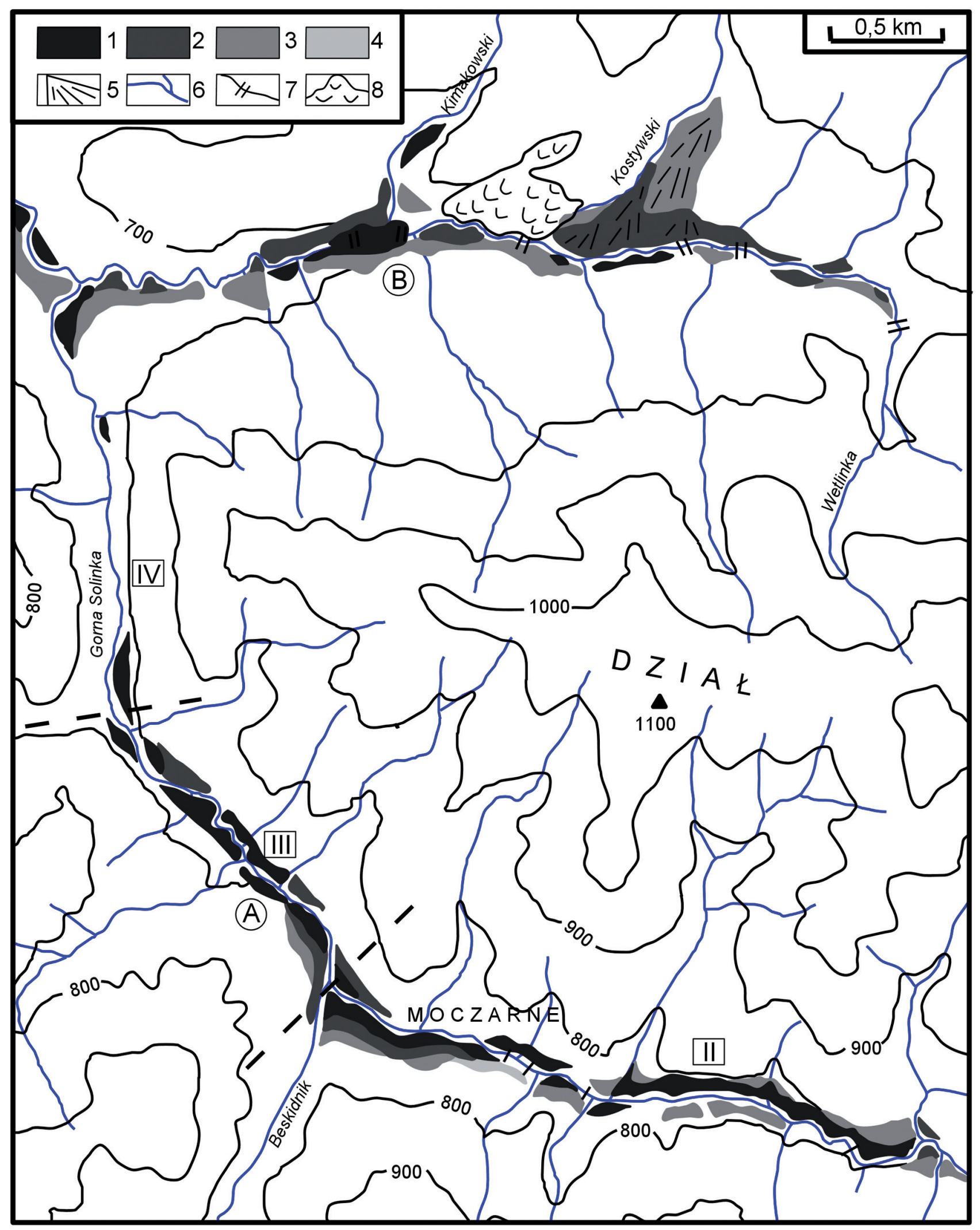

Ryc. 2. Mapa rozmieszczenia teras w dolinie Górnej Solinki (A) i Wetlinki (B)

1 - terasy holoceńskie, 2 - terasa z okresu zlodowacenia północnopolskiego (Wisły), 2 - terasa z okresu zlodowacenia środkowopolskiego, 4 - terasa z okresu zlodowacenia południowopolskiego (Sanu), 5 - stożki napływowe, 6 - sieć rzeczna, 7 - skalne progi korytowe, 8 - osuwisko; pozostałe objaśnienia jak na ryc. 1

Fig. 2. Map of distribution of terraces in the valley of Upper Solinka (A) and Wetlinka (B)

1 - Holocene terraces, 2 - Vistulian Glaciation terrace, 3 - Middle-Polish Glaciation terrace, 4 - South-Polish (Sanian) Glaciation terrace, 5 - alluvial fans, 6 - river network, 7 - bedrock steps, 8 - landslide; other descriptions as in Figure 1 
te dopływami Wetliny i dlatego ciągną się na zboczach doliny fragmentami o różnie rozległej powierzchni. Wysokości względne teras lokalnie się wahają, generalnie jednak zwiększają się z biegiem rzeki. Terasy denne (T4T6) mają płaskie i bardziej zwarte powierzchnie. Każda z nich jest oddzielona od sąsiedniej progiem o wyraźnej krawędzi. Przetrwałe płaty najwyższych teras (T2-T1) mają już zdenudowane krawędzie i złagodzone czoła, a żwiry starorzeczne przetrwały w nich resztkowo lub są przemieszczone razem z glinami zboczowymi ku dnie doliny, względnie są nadbudowane deluwiami. Przestrzenny plan rozmieszczenia teras na badanym odcinku doliny ilustrują ryc. 2 i ryc. 4.

\section{Dolina Górnej Solinki}

Dolina Górnej Solinki (A) składa się z czterech odcinków o różnym kierunku biegu (ryc. 1, 2). Jej odcinek źródłowy (I, po węzeł potoków na wysokości $801 \mathrm{~m}$ n.p.m.) ma bieg SE-NW i jest wciosem bez teras rzecznych. Odcinek następny (II, po ujście potoku Beskidnik) ma bieg E-W i wyróżnia się najlepiej rozwiniętym zespołem teras na całej długości doliny. Tylko na tym odcinku oprócz teras dennych występują również terasy zboczowe (ryc. 2, ryc. 3 - przy profilu Górnej Solinki). Pomimo wąskości dna doliny i dużej stromości zboczy przetrwały tam wąskie listwy teras wysokich: $15 \mathrm{~m}$ (T3), $30 \mathrm{~m}$ (T2). Występują one także płatowo po obu stronach rzeki, najszerzej w łukowych częściach koryta i przy wylotach bocznych dolin. Już na początku tego odcinka (II), w stożkach węzłowo zbiegających się potoków występują trzy terasy o wysokościach 1-2 m i 4-5 m (T6) oraz 7-8 m (T5), mające szerokość odpowiednio 10 m, 20 m i 20-30 m, a każda $\mathrm{z}$ nich ma pokrywę żwirów o miąższości ponad $1 \mathrm{~m}$. W dalszym biegu odcinka II najobszerniej zachowały się płaty teras 4-5 m (T5) i 8-10 m (T4). Pierwsza z nich ma w Moczarnem 35-40 m szerokości, a druga 20-40 m (na początku odcinka II po prawej stronie rzeki nawet 80-100 $\mathrm{m}$ ). Pojedynczy fragment terasy wysokiej (prawie $30 \mathrm{~m}-$ T2) na lewym zboczu doliny jest podcięty osuwiskiem. Odsłonięta w niszy osuwiskowej pokrywa grubych żwirów piaskowcowych ma ponad $3 \mathrm{~m}$ miąższości i nie jest nadbudowana deluwiami. Cokół tej terasy jest zbudowany z bardzo odpornych piaskowców ciśniańskich, co zapewne sprzyjało przetrwaniu tej terasy w mało zmienionym kształcie.

W odcinku dolnym (III, po ujście potoku Wielki Lutowy) ciągną się wzdłuż koryta jedynie wąskie listwy teras niskich (1-2 m, 2-3 m). Odcinek dolny (IV, po połączenie $\mathrm{z}$ Wetlinką) jest głębokim i wąskim przełomem rzeki, bez teras wzdłuż koryta. Dopiero od zbiegu obu rzek dno doliny zdecydowanie się rozszerza i w nim jest uformowany pełny zespół teras zarówno dennych, jak i zboczowych.

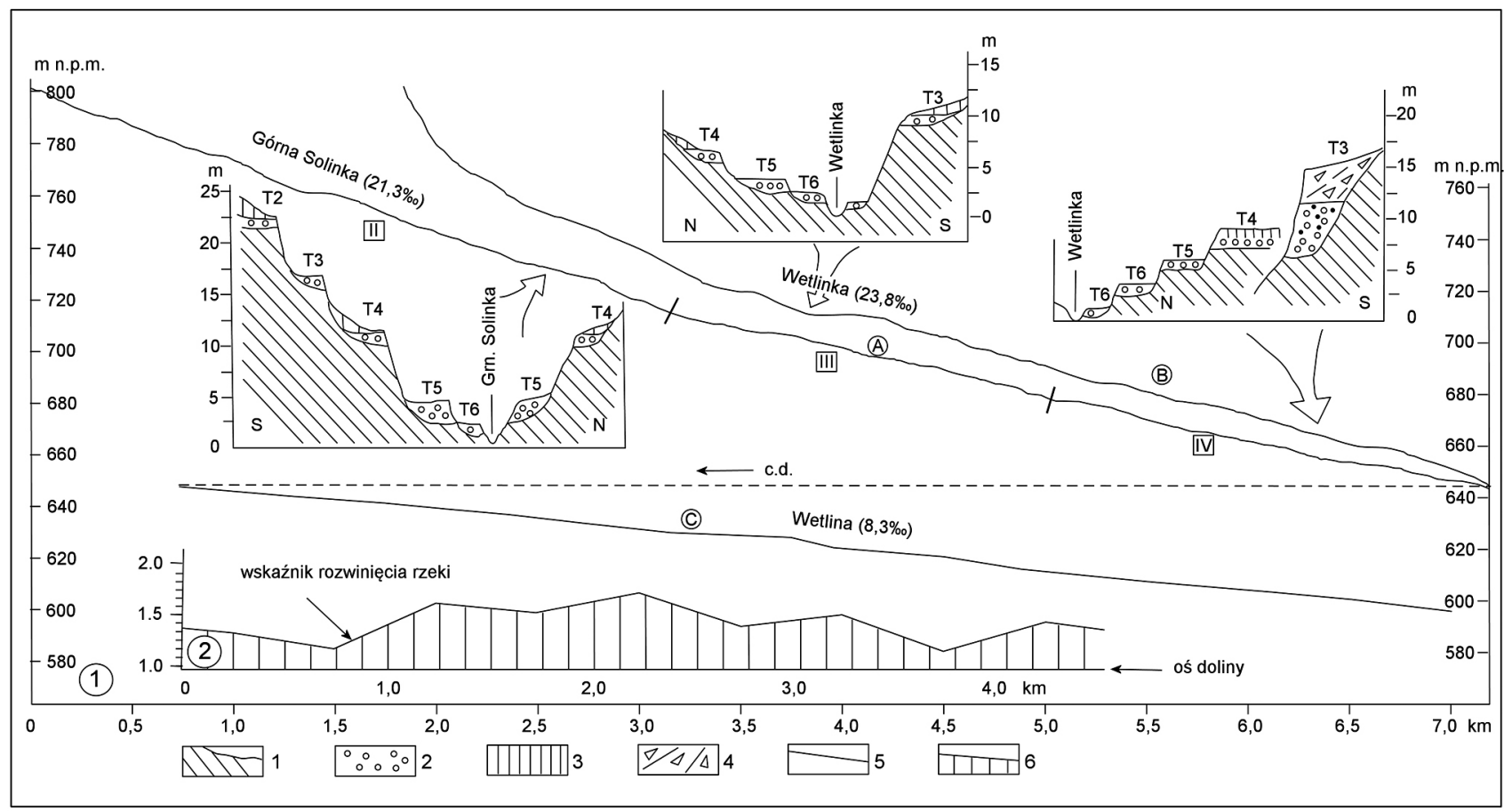

Ryc. 3. Profile podłużne badanych odcinków koryt (A, B, C) wraz z układem teras w dolinie Górnej Solinki i Wetlinki (a) oraz porównanie spadku koryta Wetliny ze wskaźnikiem rozwinięcia jej koryta (na odcinku od ujścia Górnej Solinki po ujście potoku Smerek) (b). 1 - skalne podłoże, 2 - pokrywa żwirowa, 3 - pokrywa gliniasta, 4 - osady stożka napływowego, 5 - profil podłużny koryta, 6 wskaźnik rozwinięcia rzeki; pozostałe objaśnienia jak na ryc. 1

Fig. 3. Longitudinal profiles of the studied channel reaches (A, b, C) and terraces in the valleys of the Wetlinka and Upper Solinka (a) and a comparison of the channel slope with the tortuosity of the Wetlina channel (between the mouth of Upper Solinka and Smerek Stream) (b)

1 - bedrock, 2 - gravelly cover, 3 - loamy cover, 4 - alluvial fan deposits, 5 - longitudinal profile of river channel, 6 - tortuosity; other descriptions as in Figure 1 


\section{Dolina Wetlinki}

Dolina Wetlinki ma wąskie dno (50-120 m), dlatego terasy są nieciągłe i również wąskie. Ich rozprzestrzenienie z biegiem doliny zaczyna się od wysokiego progu (ponad $2 \mathrm{~m}$ ) w korycie rzeki, w odległości ok. 4,5 km od połączenia z Górną Solinką. Próg ten jest założony na gruboławicowych piaskowcach i zapewne przez wiele faz rozcinania koryta był lokalnym progiem erozji wstecznej rzeki. Od tego progu ciągną się w dół doliny terasy o wysokości 1,0-1,5 m (T6), 2,5-3,0 m (T5) i 5-6 m (T4). Najniższa $\mathrm{z}$ nich jest w szerszych miejscach doliny dwudzielna (0,5-1,0 $\mathrm{m}$ i 1,0-1,5 m).

Blisko progu terasa 1,0-1,5 (T6) m jest osadowa, ale już po 300 m staje się skalno-osadową, ponieważ Wetlinka erodując zaczyna formować jej łupkowy cokół. Wysokość tego cokołu zwiększa się z biegiem terasy i zyskuje on stopniowo przewagę nad miąższością żwirowej pokrywy w pionowym profilu terasy. W środkowym odcinku doliny (pomiędzy ujściami potoków Kostywskiego i Kimakowskiego) terasa ma nawet 2,0 -2,5 m wysokości, ponieważ rzeka ma tam większy, progowy spadek podłużny. Bardzo cienka jest pokrywa żwirów $(0,2-0,8$ $\mathrm{m})$, za to wysoki jest cokół z ciemnych łupków. Poniżej ujścia potoku Kimakowskiego progi w korycie są jeszcze wyższe i terasa staje się dwudzielna $(0,5-2 \mathrm{~m}$, do 2-3 m). Jej niższy stopień jest nierówną powierzchnią erozyjną. Wyższa z teras Wetlinki (3,5-5,0 m - T5) podnosi się $\mathrm{z}$ biegiem doliny nawet do $5 \mathrm{~m}$, ale od środkowej części doliny ponownie się obniża do 3-4 m. Jej pokrywa żwirowa ma $0,1-0,7$ m miąższości w odcinku górnym, 1,2-1,0 $\mathrm{m}$ w części środkowej i 0,7-1,0 m w części dolnej doliny.

Kolejna terasa (6-9 m - T4) jest najwyższa w środkowym odcinku doliny (osiąga tam nawet 10 m wysokości), w dalszym biegu obniża się do wysokości początkowej (ok. $6 \mathrm{~m}$ ). Poniżej strefy progów korytowych, na 1,5 km przed połączeniem z Górną Solinką, pokrywa żwirów w tej terasie ma 2,0-2,5 m miąższości, w strefie progów do $0,5 \mathrm{~m}$, a wzdłuż osuwiska między potokami Kostywskim i Kimakowskim grube żwiry o miąższości 1,5-1,7 m są przykryte 0,5 -metrową warstwą koluwiów. W górnym biegu doliny pokrywa żwirów ma ponad 1,0 m miąższości. Mniejsze miąższości aluwiów na długości terasy są kompensowane wzrostem wysokości cokołu skalnego.

Wyższe terasy są zachowane jedynie fragmentarycznie. Lepiej z nich przetrwała terasa o wysokości 10-15 m (T3), która ciągnie się wąskim pasem po lewej stronie doliny, od połączenia Wetlinki z Kostywskim Potokiem, aż po jej połączenie z Górną Solinką. Do poziomu tej terasy nawiązują powierzchnie stożków napływowych potoków Kostywskiego, Kimakowskiego (prawa strona doliny) i potoków spływających spod grzbietu Dział (lewa strona). Aluwialna pokrywa terasy jest przykryta glinami zboczowymi, dlatego terasa ma powierzchnię nachyloną ku osi doliny.

W środkowym biegu doliny, naprzeciw dużego osuwiska (pomiędzy potokami Kimakowskim a Kostywskim), terasa (T3) ma 12 m wysokości. Na 7-metrowym cokole z ciemnych i szarych łupków zalega tam 2-metrowa warstwa żwirów (w większości o średnicy do $15 \mathrm{~cm}$ ), przykryta 3-metrową serią glin o złożonej genezie. Po drugie stronie doliny, pomiędzy wymienionymi wyżej potokami, pokrywa glin na tej terasie ma zaledwie $0,5 \mathrm{~m}$. Gruba pokrywa glin zalega też na żwirach z poziomu T3 w niższej części doliny, m.in. w odsłonięciu (15 m wysokości) na lewym brzegu rzeki, ok. 0,7 km przed połączeniem z Górną Solinką. Profil tego odsłonięcia jest następujący: na 5-metrowym cokole stromo ułożonych łupków zalega ok. 5-metrowa seria żwirów złożona z trzech poziomów otoczaków bardzo grubych (do $40 \mathrm{~cm}$ długości osi a) przedzielonych dwoma poziomami otoczaków średniej wielkości. Na nich zalega 4,5-5-metrowa pokrywa piaszczystej gliny z grubym gruzem pochodzenia soliflukcyjnego, maskująca aluwia (ryc. 3 - przy profilu Wetlinki). Zbocze doliny jest w tym miejscu strome i gdyby Wetlinka go nie podcięła to żwiry terasy nie byłaby widoczne.

Jedyny fragment terasy najwyższej $\mathrm{w}$ tej dolinie (>20 m - T2) jest typu erozyjnego. Jest nim spłaszczenie lewostronnego garbu międzydolinnego, na wysokości 700-707 m n.p.m., ok. $1 \mathrm{~km}$ przed wylotem doliny. Na jego powierzchni nie ma aluwiów, nawet pokrywa gruzowo-piaszczysta jest tam bardzo cienka (do $20 \mathrm{~cm}$ ). Jest możliwe, że jest to $\mathrm{w}$ całości spłaszczenie strukturalne, bez związku genetycznego z rozciągłością poziomu terasy $\mathrm{T} 2$.

W rzeźbie doliny Wetlinki wyróżniają się dużymi rozmiarami stożki napływowe potoków Kostywskiego i Kimakowskiego. Pierwszy z nich ma prawie $1 \mathrm{~km}$ długości. Jest on stożkiem podwójnym, złożonym z poziomu wyższego (5-10 m wysokości) i niższego (3-4 m) - włożonego w erozyjną rynnę w stożku wyższym. Oba te stożki są złożone $\mathrm{z}$ niewysortowanych grubych otoczaków upakowanych w piasku i nadbudowane warstwą gliny z gruzem i otoczakami. Warstwa gliny na stożku niższym ma miąższość $0,3-0,6 \mathrm{~m}$, na stożku wyższym 1,2-1,5 m. W częściach dystalnych każdego ze stożków miąższość aluwiów przekracza ich względne wysokości. Dopiero w górnej połowie stożków odsłaniają się ich skalne cokoły i szybko wzrastają do 2 m wysokości (w stożku niższym) i 5-6 m (w stożku wyższym).

\section{Dolina Wetliny}

W dolinie Wetliny (C) terasy są bardziej rozległe i wyższe. Rozprzestrzenienie teras wzdłuż koryta rzeki jest nierównomierne. W górnej części wsi Wetlina terasy są rozległe po lewej stronie koryta, w środkowej części wsi po stronie prawej, a poniżej Starego Sioła ponownie po stronie lewej (ryc. 4).

Najwyższy poziom spłaszczeń o cechach terasy erozyjnej rozciąga się u podnóża stoków Połoniny Wetlińskiej (prawa strona doliny) i Jawornika (strona lewa) na wysokości 700-715 m n.p.m., tj. ok. 70-60 m nad korytem rzeki. Ciągnie się on nad wsią Wetlina szerokimi $(0,3-0,5 \mathrm{~km})$ i łagodnie nachylonymi $\left(3-6^{\circ}\right)$ pasami po obu stronach doliny. Ciągłość tych spłaszczeń przerywają 


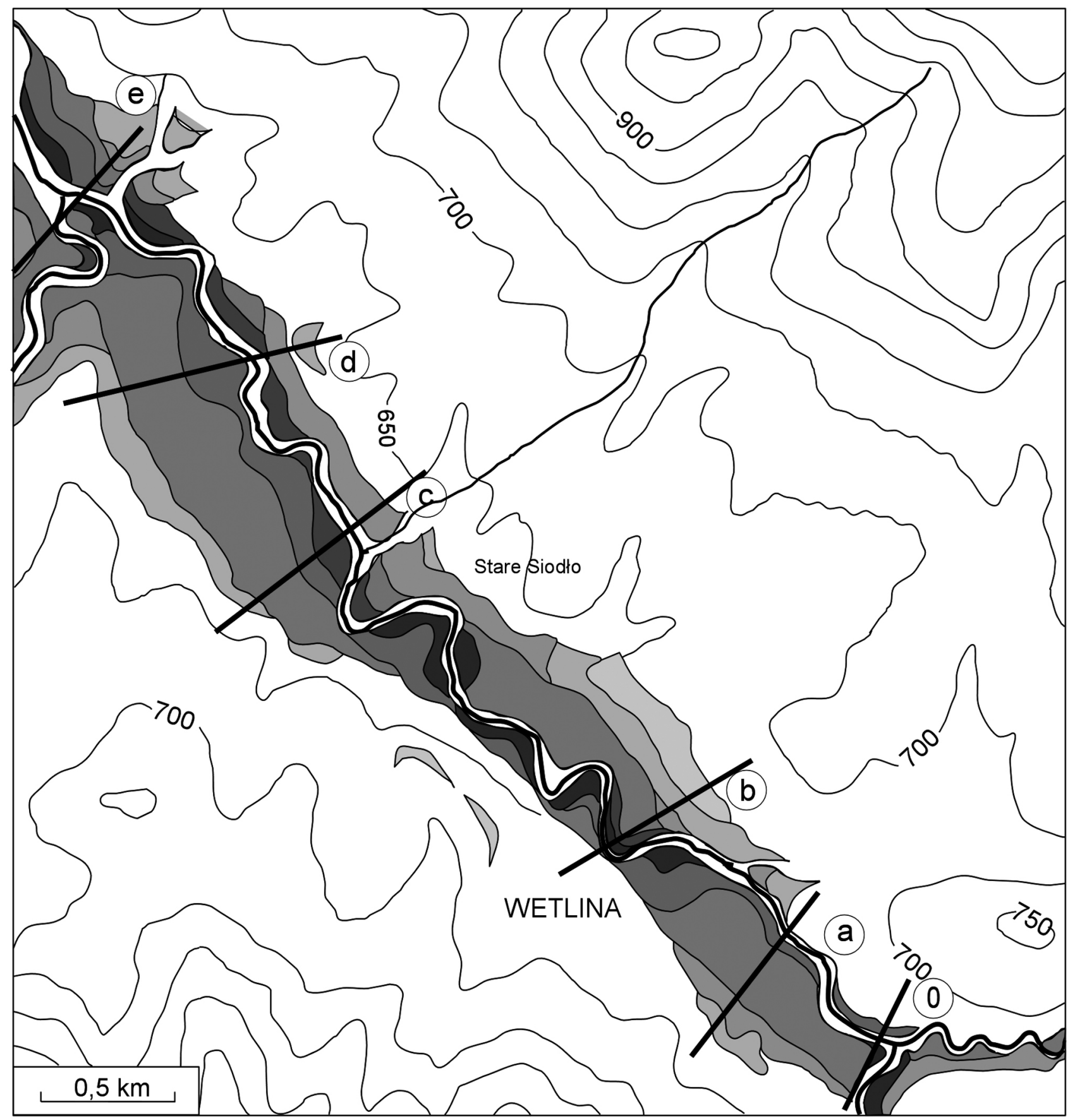

Ryc. 4. Mapa rozmieszczenia teras w dolinie Wetliny $(\mathrm{C}$ - poniżej połączenia Wetlinki z Górną Solinką) i linie przekrojów doliny $(0$, a, b, c, d, e - tak jak na ryc. 5). Inne objaśnienia jak na ryc. 2

Fig. 4. Map of distribution of the terraces in the valley of Wetlina river $(\mathrm{C}$ - downstream of the confluence of Wetlinka and the Upper Solinka) and valley cross-section lines ( $0, \mathrm{a}, \mathrm{b}, \mathrm{c}, \mathrm{d}, \mathrm{e}-$ as in Figure 5). Other descriptions as in Figure 2

boczne dopływy Wetliny, wcięte na głębokość 20-40 m, dlatego każde ze spłaszczeń ma obecnie kształt szerokiego garbu międzydolinnego.

Na powierzchni tych garbów nie stwierdzono zwartej pokrywy żwirowej. Płytkie wkopy (do $1 \mathrm{~m}$ ) ujawniły jedynie zaleganie tam zwietrzeliny gliniasto-ilastej lub gliniasto-piaszczystej z gruzem. Być może pozostałością pokrywy żwirowej są pojedyncze otoczaki tkwiące w piaszczystej glinie, odsłonięte $\mathrm{w}$ wykopach na prawym garbie nad Starym Siołem (715 m n.p.m.). Otoczaki te są piaskowcowe, średnioziarniste, o wielkości 8-22 cm, sła- bo obtoczone i w różnym stopniu zwietrzałe. Po drugiej stronie doliny, u podnóży Jawornika (garb 722 m n.p.m.), na wysokości ponad 700 m (60 m n.p. rzeki) obecność podobnych otoczaków stwierdził Malarz (2001). Większość otoczaków ma tam grube koncentryczne otoczki żelaziste. Ok. $1 \mathrm{~km}$ na SE w tym samym poziomie pojedyncze otoczaki znajdują się także nad kościołem w Wetlinie. O żwirach na tym poziomie w Smereku (ok. $700 \mathrm{~m}$ n.p.m.) pisał Starkel (1965).

Najwyższy poziom dobrze zachowanych żwirów (T1) ciągnie się na wysokości 675-690 m n.p.m. (40-55 m 


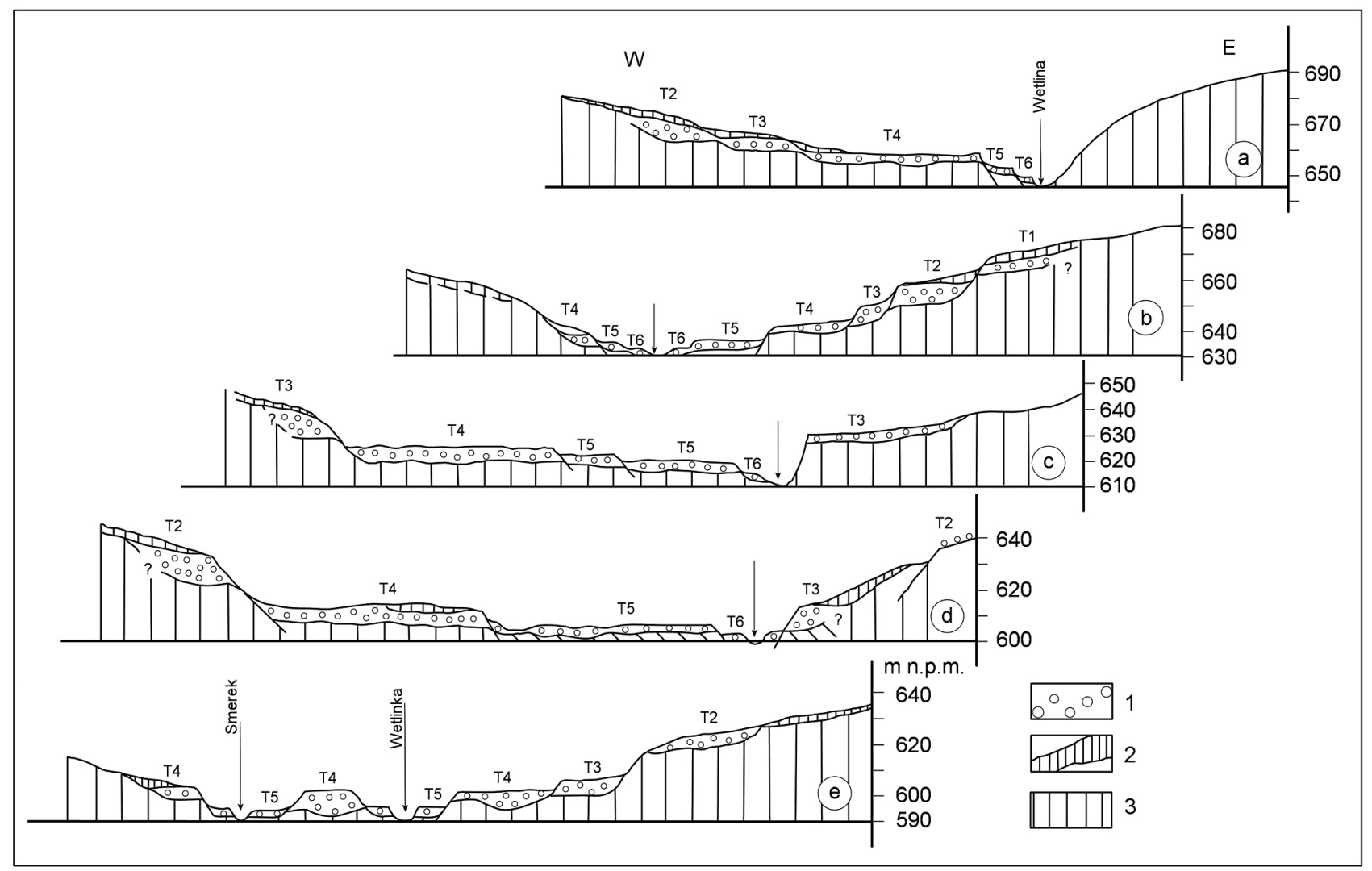

Ryc. 5. Przekroje poprzeczne doliny Wetliny (a, b, c, d, e) wraz z układem teras (na odcinku C - od ujścia Górnej Solinki po ujście potoku Smerek)

1 - pokrywy żwirowe, 2 - pokrywy gliniaste, 3 - skalne podłoże; linie przekrojów doliny a, b, c, d, e zaznaczono na ryc. 4

Fig. 5. Cross-sections of the Wetlina valley (a, b, c, d, e) and river terraces (C - between the mouth of Upper Solinka and confluence of Smerek Stream)

1 - gravelly covers, 2 - loam covers, 3 - bedrock; cross-sections a, b, c, d, e marked in Figure 4

nad rzeką) na prawym zboczu doliny w środkowej części wsi (ryc. 4). Tam leje źródłowe okresowych cieków są wyścielone grubymi (do $30 \mathrm{~cm}$ długości osi a) otoczakami z gruboziarnistych piaskowców, silnie zwietrzałymi i upakowanymi w piaszczystej glinie. Więcej gliny jest przy powierzchni lejów, głębiej dominują żwiry. Warstwa glin ze żwirami ma ponad $3 \mathrm{~m}$ miąższości, podobnie jak w odsłonięciu nad miejscową szkołą, gdzie budowa pokrywy żwirowej (ok. 2 m miąższości) jest lepiej zachowana i otoczaki są mniej zwietrzałe.

Obszerniej zachował się poziom terasy T2 o wysokości względnej 20-30 m (ryc. 4, ryc 5). Jego fragmentem jest spłaszczenie prawego zbocza doliny w środkowej części wsi, bezpośrednio poniżej terasy T1. Spłaszczenie to jest szerokie (30-100 m) i nad terasą niższą (T3) wnosi się 10-metrowym progiem. Warstwa żwirów ma tam ok. $3 \mathrm{~m}$ miąższości i jest cienko nadbudowana glinami zboczowymi. Grube otoczaki z piaskowców średnioi gruboziarnistych są wyraźnie zwietrzałe. Po tej stronie doliny nawiązuje do poziomu T2 także stanowisko otoczaków pojedynczo rozproszonych $\mathrm{w}$ glinie na wysokości 625-630 m n.p.m. (25-30 m n.p. rzeki) ok. $1 \mathrm{~km}$ poniżej mostu w Starym Siole. Tam w ścianach wciosu drogowego i powyżej jego zamknięcia występują w piaszczysto-ilastej glinie $\mathrm{z}$ gruzem $(1,2 \mathrm{~m}$ miąższości) średnie i grube otoczaki z piaskowców średnioziarnistych, silnie zwietrzałe (przekrój d na ryc. 5). Po lewej stronie doliny terasa 25-30 m (T2) ciągnie się od mostu w Starym Siodle w kierunku północnym po dolinę potoku Smerek. Ma ona bardzo miąższą pokrywę żwirów (aż 7-9 m) (ryc. 5 - przekrój d; ryc. 6 - profil d). Wznosi się nad terasą niższą (T4) stromą i wysoką skarpą z osuwiskami i złaziskami, obniżającą się w kierunku północnym z $15 \mathrm{~m}$ do $10 \mathrm{~m}$. Pochyłość powierzchni tej terasy wynika z częściowej redukcji pokrywy żwirowej w strefie przykrawędziowej oraz nadbudowy tej pokrywy glinami deluwialnymi w strefie przyzboczowej. Żwiry są głównie z piaskowców gruboziarnistych i zlepieńcowatych, o spoiwie żelazisto-krzemionkowym. Grube otoczaki są dobrze obtoczone i w różnym stopniu zwietrzałe.

Terasa niższa (12-15 m - T3) zachowała się obszernie jedynie na prawym brzegu Wetliny w dolnej części doliny (ryc. 4). Jej długi (ok. $1 \mathrm{~km}$ ) fragment wznosi się tam na wysokiej skarpie bezpośrednio nad korytem rzeki, miejscami podcinanej przez Wetlinę. W podcięciach terasy odsłania się warstwa żwirów o różnej miąższości: od 1,82,5 $\mathrm{m}$ w południowej części skarpy, do 3-4 $\mathrm{m}$ (miejscami nawet $6 \mathrm{~m}$ ) w części północnej. Piaskowcowe otoczaki są gęsto spękane, upakowane w piaszczystej, zwietrzelinowej glinie. Warstwa żwirów jest przykryta gliną z gruzem pochodzenia deluwialnego o miąższości $0,3-1,0 \mathrm{~m}$ (ryc. 6 - profil e). 


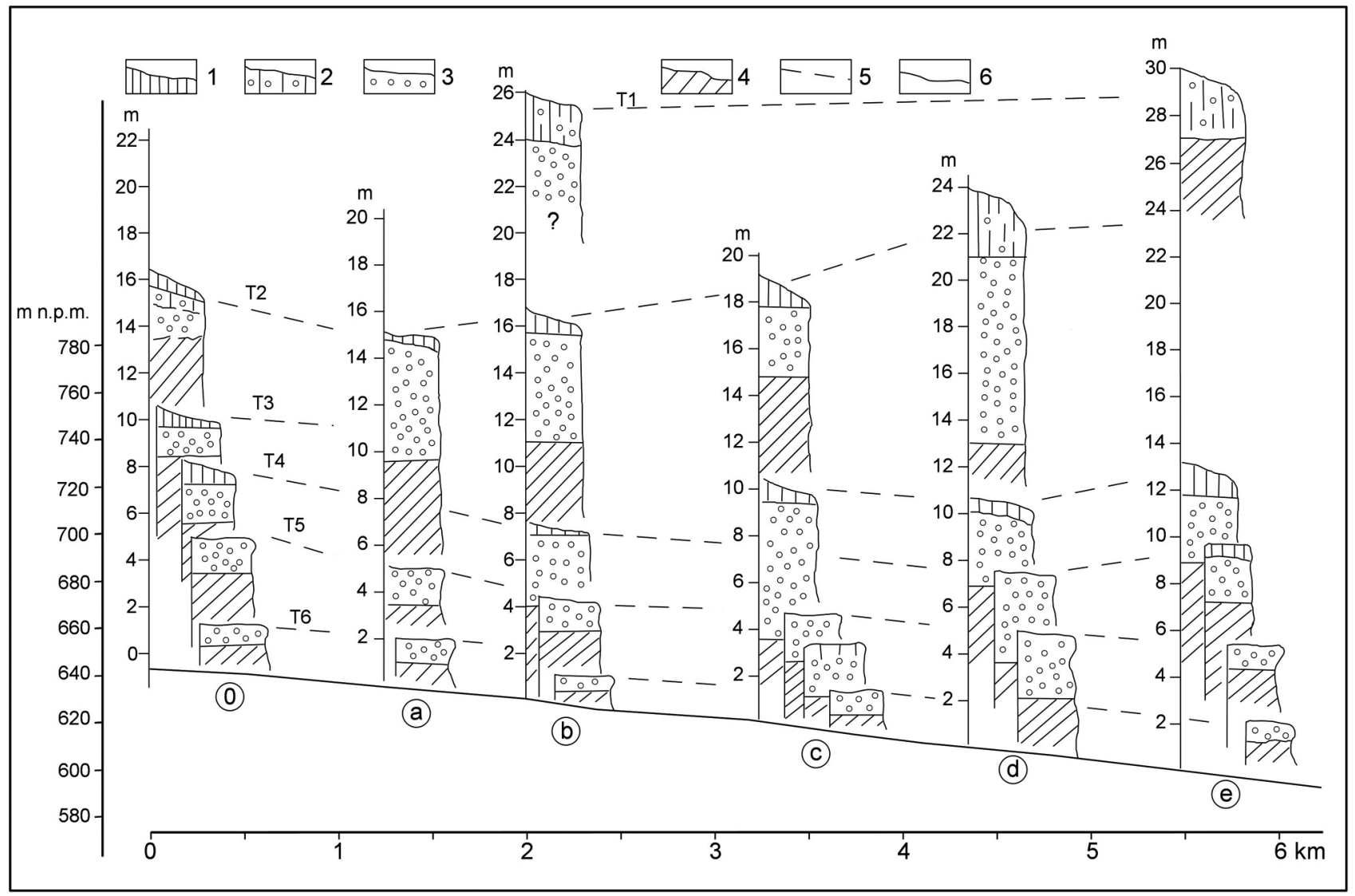

Ryc. 6. Wysokości względne i budowa wewnętrzna teras Wetliny wzdłuż profilu podłużnego rzeki (na odcinku od ujścia Górnej Solinki po ujście potoku Niedźwiedzi w Smereku)

T1 - terasa z okresu zlodowacenia południowopolskiego (Sanu), T2 - terasa z okresu zlodowacenia środkowopolskiego, T3 - terasa z okresu zlodowacenia północnopolskiego (Wisły), T4 - terasa późnoglacjalna, T5 i T6 - terasy holoceńskie; 1 - pokrywy gliniaste, 2 - pokrywy gliniasto-żwirowo-gruzowe, 3 - pokrywy żwirowe, 4 - skalne podłoże teras, 5 - linie korelacyjne teras, 6 - krzywa profilu podłużnego Wetliny

Fig. 6. Elevation and structure of the terraces of Wetlinka Stream along its longitudinal profile (between the mouth of the Upper Solinka and Niedźwiedzi Stream at Smerek)

T1 - South-Polish (Sanian) Glaciation terrace, T2 - Middle-Polish Glaciation terrace, T3 - North-Polish (Vistulian) Glaciation terrace, T4 - Late Glacial terrace, T5 - and T6 - Holocene terraces; 1 - loam covers, 2 - loamy-gravelly-debris covers, 3 - gravelly covers, 4 - terrace bedrock, 5 - terrace correlation levels, 6 - longitudinal profile of Wetlina River

Najbardziej rozległa w dolinie Wetliny jest terasa T4 (7-10 m; ryc. 4 i ryc. 5). Na jej powierzchni skupia się większość zabudowy wsi Wetlina. Po lewej stronie koryta w południowej części wsi ma ona do 250 m szerokości, a w północnej - od Starego Sioła po Smerek - nawet 350 m. Jej pokrywa aluwialna ma przeważnie 2-3 m miąższości (miejscami nawet 4 m) (ryc. 6 - profil d; ryc. 7). Budowa tej pokrywy jest zróżnicowana. W części dolnej dominują grube, często imbrykowane żwiry z piaskiem, wyżej przeważają żwiry drobniejsze z wkładkami piasku i mułku, miejscami są one warstwowane. Na płaskiej powierzchni terasy usypane są stożki napływowe bocznych potoków Wetliny oraz są wycięte płytkie, podmokłe starorzecza $\mathrm{z}$ mułkowo-torfowym wypełnieniem. W tych obniżeniach rozwijają się w kierunku potoku Smerek torfowiska niskie.

Niższymi stopniami dna doliny są terasy o wysokości 5-6 m (T5) oraz 3-4 m i 2-3 m (T6) Są one oddzielone od siebie wyraźnymi krawędziami erozyjnymi (ryc. 5). Małe są różnice $\mathrm{w}$ wysokości tych teras, ale mają one własne pokrywy aluwialne i różną wysokość skalnych cokołów. Ich pokrywy żwirowe są cienkie (1,0-1,5 m), bez nadbudowy glinami (ryc. 8). Słabe zwietrzenie żwirów, względnie luźne ich upakowanie i brak konsolidacji dowodzą względnej młodości tych pokryw, a tym samym również wieku powstawania teras. Zestawienie ilości teras i ich względnych wysokości na całej długości doliny Wetliny przedstawia tab. 1.

\section{Lokalne wahania wysokości teras}

W powyższym opisie teras Wetliny sygnalizowano częste występowanie wahań ich wysokości względnej, nierównej miąższości pokrywy aluwialnej i tym samym także wysokości skalnych cokołów. Miejsca tych wahań nawiązują przestrzennie do odcinków wyraźnych zmian spadku w profilu podłużnym koryta. Na odcinkach koryt z progami skalnymi, gdzie zwiększa się spadek profilu koryta, zyskują wysokość wszystkie terasy, natomiast na odcin- 


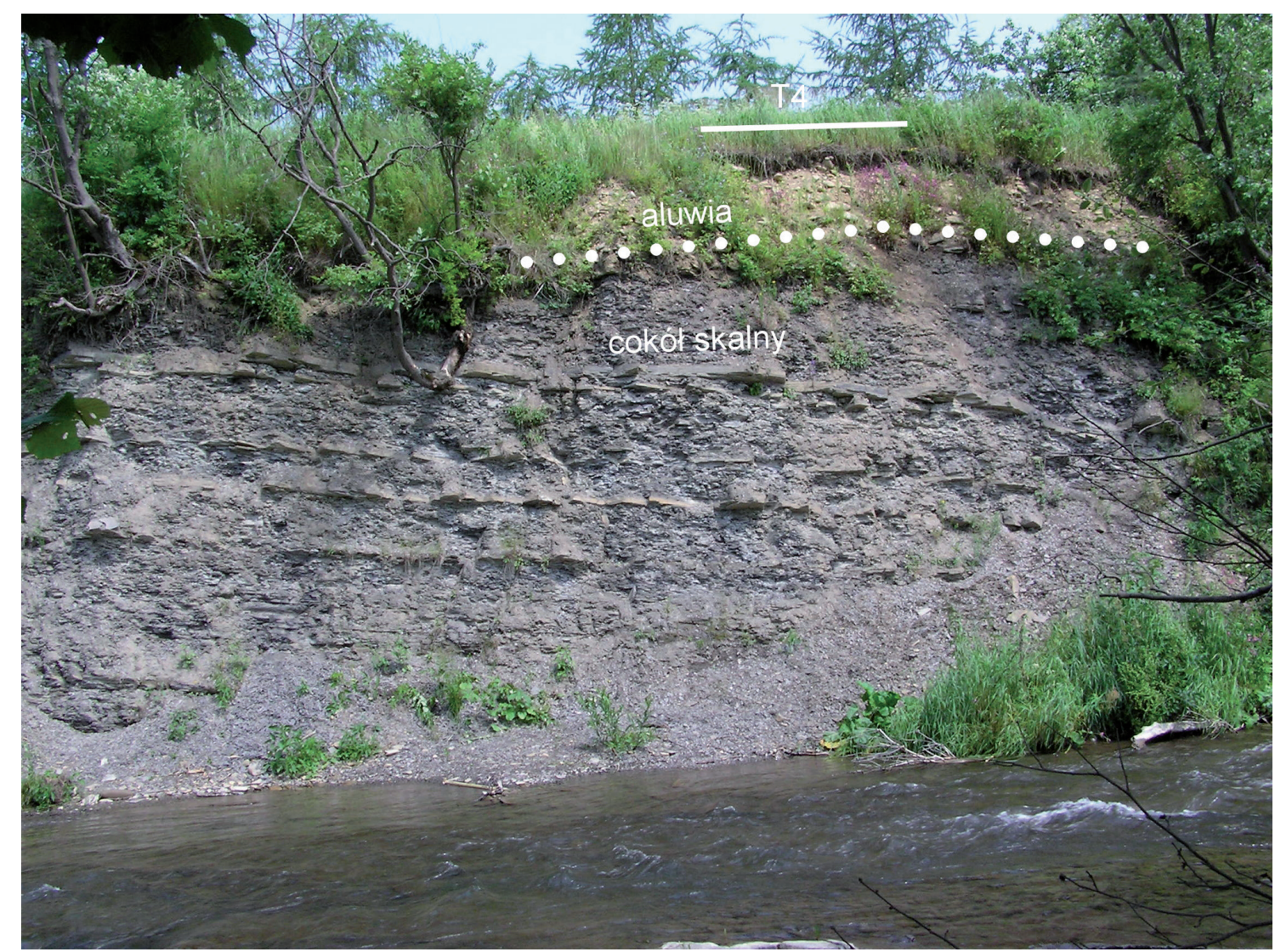

Ryc. 7. Terasa 10 m (T4) w Wetlinie (fot. G. Haczewski)

Fig. 7. $10 \mathrm{~m}$ - terrace (T4) at Wetlina (Photo: G. Haczewski)

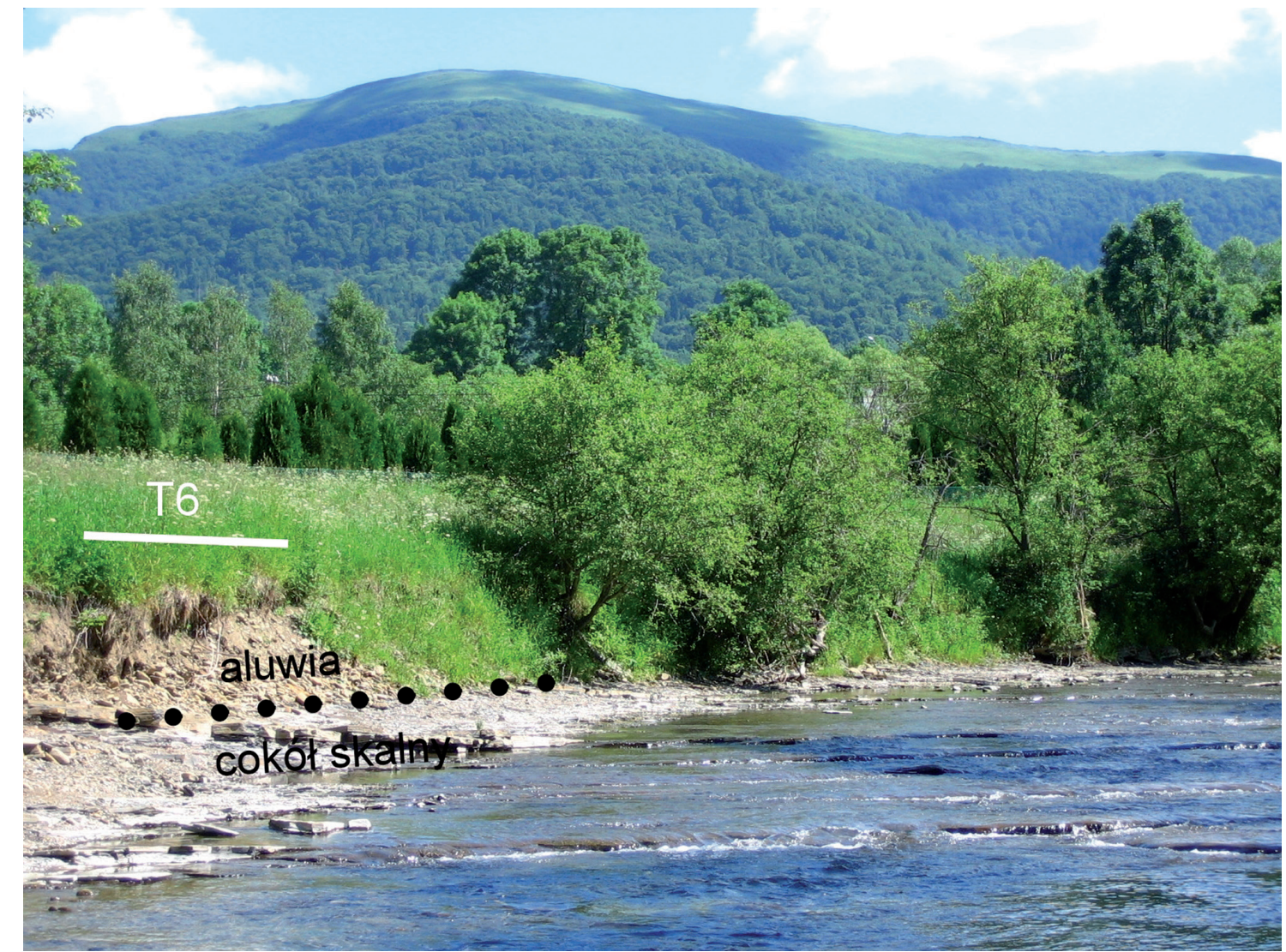

Ryc. 8. Żwirowa terasa Wetliny o wysokości 1,5 m (T6) (fot. K.Bąk)

Fig. 8. 1.5 m gravelly terrace of Wetlina River (T6) (Photo: K.Bąk) 


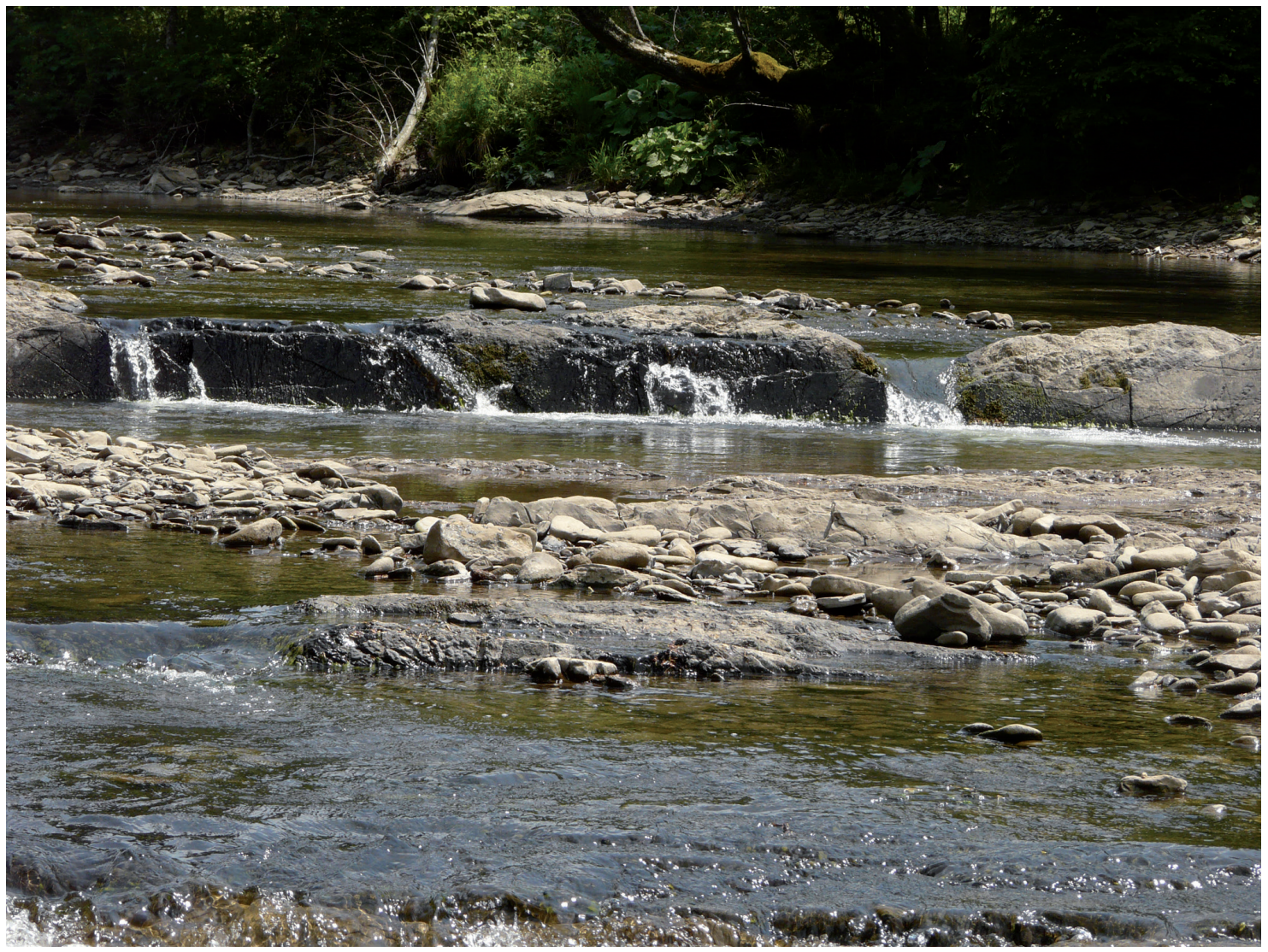

Ryc. 9. Progi skalne w korycie Wetliny (fot. G.Haczewski)

Fig. 9. Bedrock steps in the channel of Wetlina River (Photo: G.Haczewski)

kach wyraźnego złagodnienia profilu podłużnego maleją wysokości teras niskich (głównie T5, T6).

Krzywa profilu podłużnego rzeki ma odcinki zwiększonego spadku w kilku miejscach. Są to obecnie odcinki skalnego koryta rzeki z licznymi progami lub bystrzami (ryc. 9). Koryto Górnej Solinki (A) ma kilkakrotne progowe załamania profilu, czego następstwem są gwałtowne lokalnie zmiany wysokości teras. M.in. terasa T6 (1,5-2 m) w II odcinku doliny, na długości $400 \mathrm{~m}$, zwiększa wysokość do 3,5-4 m, a po dalszych $500 \mathrm{~m}$ ponownie się obniża do $2 \mathrm{~m}$. Podobnie jest z terasą T5 (4 m), która w Moczarnem na długości tylko $80 \mathrm{~m}$ ma wysokość 6 $\mathrm{m}$, a po dalszych $100 \mathrm{~m}$ obniża się ponownie do 4-5 m. W tym miejscu przyczyną tak gwałtownej zmiany wysokości terasy było powstanie zapory drzewnej w korycie, jej wypełnienie osadami, a następnie erozyjne rozcięcie. Wskazuje na to zdecydowane zdrobnienie i warstwowa budowa aluwiów na krótkim odcinku terasy oraz obecność w nich subfosylnych pni drzew.

Wzdłuż Wetlinki (B) występuje ogólna tendencja wzrostu wysokości teras, niezależnie od załamań profilu koryta, jakkolwiek w sąsiedztwie progów korytowych terasy T4, T5 i T6 są wyższe. Zaznacza się szczególnie w środkowym odcinku doliny - pomiędzy ujściami potoków Kostywskiego i Kimakowskiego i poniżej tego drugiego. Tam terasa T4 (5-9 m) na długości ok. 0,7 km zwiększa wysokość z $6 \mathrm{~m}$ do prawie $10 \mathrm{~m}$, natomiast w wylotowym odcinku Wetlinki obniża się do 6-7 m.
Poniżej połączenia Górnej Solinki z Wetlinką (odcinek C) wszystkie terasy są wyższe. Terasa T4 (5-9 m) już po ok. 0,6 km osiąga wysokość 8-10 m, niższa - T5 (4-5 m) ma $6 \mathrm{~m}$, a wyższa - T3 (10-12 m) nawet 15 m. Wyraźniej zaznacza się dwudzielność terasy T6, jej wyższy stopień zwiększa wysokość z $2 \mathrm{~m}$ do 3,5-4 m, natomiast niższy (1,5 m) utrzymuje podobną wysokość na całej długości odcinka C. Szczególnie częste zmiany wysokości na krótkich odcinkach ma terasa T5 (od $4 \mathrm{~m}$ do $6 \mathrm{~m}$ ). Terasa ta ma cienką pokrywę żwirową, miejscami tylko 0,5-1,0 m, za to wysoki jest jej łupkowy cokół $(5,0-5,5 \mathrm{~m})$. Wyższe terasy mają bardziej miąższe pokrywy aluwialne niż w dolinach źródłowych. Ogólnie można stwierdzić, że większa wysokość teras na odcinku $\mathrm{C}$ wynika zarówno z podniesienia ich cokołów, jak i przyrostu miąższości pokrywy aluwiów, jakkolwiek na długości teras nie jest to regułą. Różne proporcje wysokości cokołów i grubości pokryw aluwialnych w poszczególnych terasach mogą też wynikać z faktu, że w dzisiejszych podcięciach teras odsłaniają się fragmenty dna doliny znajdujące się dawniej w różnej odległości od koryta. Im bliżej dawnego koryta tym niższy może być cokół teras, a grubsza pokrywa (Starkel 2003).

\section{Wysokości teras a krzywa krętości koryta (wskaźnik rozwinięcia rzeki)}

Stwierdzono kartometrycznie i sprawdzono w terenie występowanie powiązań pomiędzy lokalnymi zmianami 
wysokości teras z krzywą krętości współczesnego koryta Wetliny na odcinku C. Koryto rzeki na tym odcinku ma długość $6,4 \mathrm{~km}$, a symetryczna biegnąca oś doliny jedynie $4,5 \mathrm{~km}$. Pomiary wskaźnika rozwinięcia koryta na jego dziewięciu odcinkach po $0,5 \mathrm{~km}$ długości wykazały spore wahania tego wskaźnika - od 1,1 do 1,7 (ryc. $3 b)$. Najwyższe wartości $(>1,5)$ osiąga koryto na odcinku 1,0-2,5 km poniżej połączenia z Górną Solinką, najmniejsze $(1,1-1,14)$ tuż poniżej tego połączenia oraz ok. $0,5-1,2 \mathrm{~km}$ przed Smerekiem. Przyjmując, że wartości tego wskaźnika powyżej 1,5 klasyfikują Wetlinę i jej koryto do grupy rzek meandrowych (Klimaszewski 1978), można twierdzić o krętym ogólnie biegu rzeki. Jest jednak bardzo istotne, że najwyższe wartości wskaźnika rozwinięcia rzeki nie nawiązują przestrzennie do odcinków o małym spadku podłużnym koryta, ale są od nich niezależne. Zatem przyczyną aktualnej krętości rzeki nie jest bezpośrednio lokalna zmienność jej spadku podłużnego (średnio 8,3\%o).

Lokalne zmiany wskaźnika krętości koryta na badanym odcinku doliny słabo uwidaczniają się w przestrzennym zróżnicowaniu wysokości teras niskich (dennych). W hipsometrii tych teras (2-3 m, 4-6 m) bardziej czytelne jest pochylenie ich powierzchni w kierunku koryta, a w odsłonięciach ich budowy ujawnia sie ześlizgowy kształt cokołu skalnego. Obniżanie się cokołów w tych terasach jest zwykle rekompensowane przyrostem miąższości ich pokryw aluwialnych. Wahania wysokości względnej tych teras nie przekraczają $1 \mathrm{~m}$. W przypadku hipsometrii teras wyższych (zboczowych) czytelność tego typu powiązań jest generalnie trudna do ustalenia. Jedynie w tych miejscach, gdzie rzeka bezpośrednio podcina terasy (7-10 $\mathrm{m}, 12-15 \mathrm{~m}$ ) to ich górne krawędzie, erozyjnie cofnięte w górę zboczy, są naturalnie wyższe z uwagi na ogólną pochyłość powierzchni tych teras w kierunku osi doliny. Denudacja żwirowych pokryw teras lub ich nadbudowa młodszymi deluwiami czyni powierzchnie tych teras pochylonymi ku osi doliny. Potwierdza się ta prawidłowość $\mathrm{m}$.in. w podcięciach terasy $12-15 \mathrm{~m}$ (prawy brzeg) w Starym Siole (północny przysiółek Wetliny).

\section{Dyskusja wyników}

\section{Wiek teras}

Osady teras Wetliny na opisywanym odcinku doliny nie były dotąd datowane metodami bezwzględnymi. Ich wiek można jedynie szacować na podstawie wskaźników hipsometrycznych, pozycji w schodowym układzie poziomów oraz stopnia zachowania samych form i zwietrzenia żwirów w ich akumulacyjnych pokrywach. W żadnej pokrywie akumulacyjnej teras plejstoceńskich powyżej Smereka nie znaleziono wkładek osadów organicznych, przydatnych do datowania ich wieku bezwzględnego metodą ${ }^{14} \mathrm{C}$.

Jedynym reperem dla oszacowania wieku teras są daty radiowęglowe torfu z torfowiska Smerek opublikowane przez Ralską-Jasiewiczową $(1969,1980)$. Jest ono usytuowane na terasie-stożku potoku Bystry w Smereku, w bezpośrednim sąsiedztwie terenu badanego. W tym miejscu wysokość terasy-stożka wynosi 9-12 m i nawiązuje rozciągłością do poziomu terasy Wetliny T4 $(9-10 \mathrm{~m})$ powyżej i poniżej wylotu potoku Smerek. Ze szczegółowego opisu tego stanowiska przez Ralską-Jasiewiczową (1980) wynika, że terasa-stożek ma tam 7-metrowy cokół i 5-metrową pokrywę ze żwirów, piasków, mułu i głazów. Na osadach mułowo-piaszczystych i ilastych zalegają warstwy torfu, których wiek w części spągowej (z głębokości 2,3 m) oznaczono na $4290 \pm 100$ BP (subboreał) i w części wyższej (z głębokości 1,3 m) na $2730 \pm 100$ BP (subatlantyk). Oznaczono tam również wiek szczątków flory (drewno, matriks) z podtorfowej, aluwialnej (mułkowej) pokrywy podłoża torfowiska: 16 925 $\pm 325 \mathrm{BP}$ (z głębokości 3,4 m) i 10 035 70 BP (z głębokości 3,7 m). Pomimo wątpliwości natury technicznej co do uzyskanych oznaczeń wieku kopalnej flory z aluwiów (Ralska-Jasiewiczowa 1980) to dolna część pokrywy aluwialnej terasy jest niewątpliwie późnoglacjalna. Terasa z torfowiskiem była jeszcze w starszym holocenie zalewana przez Wetlinę, która w tym czasie miała jeszcze koryto migrujace. Dopiero $w$ atlantyku pogtębiła koryto, a boczne stawy (mokradta) zaczęty zarastać torfem najpierw przejściowym (Ralska-Jasiewiczowa 1980).

Przyjmując wskazany wiek osadów w profilu torfowiska Smerek na terasie-stożku za reperowy można uznać wiek tej terasy za późnoglacjalno-wczesnoholoceński (z osadami późnego glacjału i starszego holocenu w pokrywie akumulacyjnej). Tym samym taki sam wiek (PG) można by przypisać terasie T4 $(6-10 \mathrm{~m}) \mathrm{w}$ dolinie Górnej Solinki, $(6-9 \mathrm{~m})$ wzdłuż Wetlinki i $(7-10 \mathrm{~m})$ wzdłuż Wetliny po Smerek (tab. 1). To najwyższa i najbardziej rozległa terasa denna w tej dolinie, bez nadbudowy deluwiami stokowymi. Poziomy wyższych teras (zwłaszcza osady ich pokryw akumulacyjnych) można tym samym uznać za plejstoceńskie: osadom w terasie T3 (11-15 m) przypisać należy okres zlodowacenia północnopolskiego (Wisły), w terasie T2 o wysokości 16-30 m) (Górna Solinka), ponad $20 \mathrm{~m}$ (Wetlinka) i 20-30 m (Wetlina) okres zlodowacenia środkowopolskiego, a $\mathrm{w}$ terasie $\mathrm{T} 1$ o wysokości 40-50 m (Wetlina) okres zlodowacenia południowopolskiego (Sanu). Żwiry zachowane resztkowo w Wetlinie ok. $60 \mathrm{~m}$ nad korytem rzeki (Malarz, 2001, 2007) byłyby jeszcze starsze - (dolnoczwartorzedowe), korelowane z najwyższym poziomem występowania żwirów w Smereku i Polankach (ok. 100 m) w dolnym biegu Wetliny i Solinki (Starkel, 1965). Pokrywy dwóch (lokalnie trzech) teras niższych (T5, T6) od terasy poźnoglacjalnej (T4) z datowanym torfowiskiem oraz samo wycięcie tych teras należy uznać za holoceńskie (ryc. 10).

Tak ustalony wiek teras Wetliny nie jest jednak pewny i wymaga potwierdzenia metodami datowania bezwzględnego. Jest wielce prawdopodobne, że z okresu zlodowacenia środkowopolskiego lub północnopolskiego pochodzą dwie (stadialne) pokrywy żwirów, dziś zalegające na różnych wysokościach względnych. Tak jest m.in. w wie- 


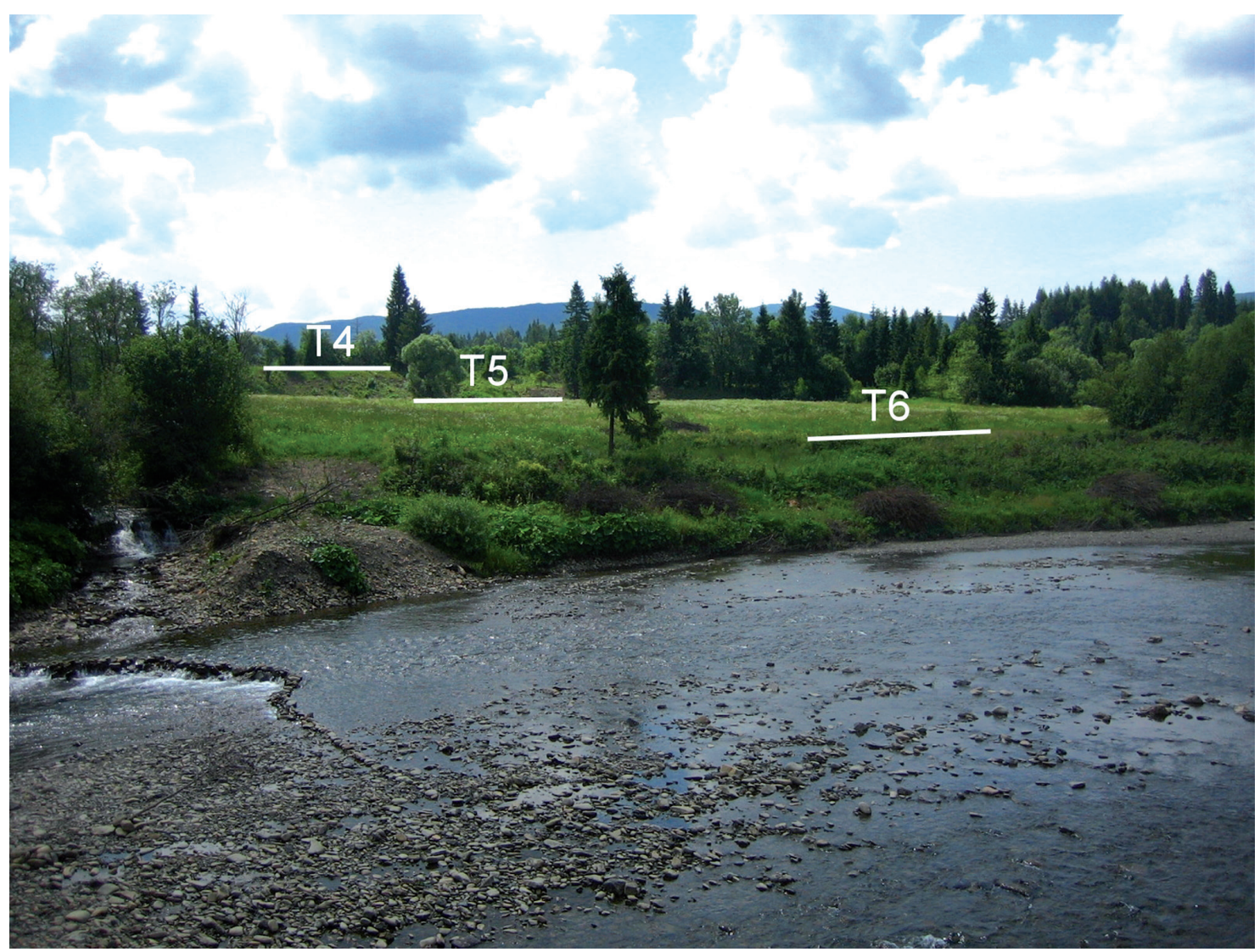

Ryc. 10. Stopnie teras Wetliny (T4, T5, T6) koło Smolnika (fot. K. Bąk)

Fig. 10. Terraces of Wetliny River (T4, T5, T6) near Smolnik (Photo: K. Bąk)

lu dolinach karpackich (Stupnicka, Szumański 1957), np. nad Sanem (Starkel 1966, 1995, 2003, Haczewski i in. 2001), Dunajcem i jego dopływach (Baumgart-Kotarba 1991-92, Zuchiewicz 1992, Lindner i in. 1993, Olszak 2011). Wówczas najwyższe terasy Wetliny byłyby znacznie młodsze.

\section{Analogie wykształcenia teras Wetlinki $\mathrm{z}$ terasami Sanu}

Schemat ilościowy i wiekowy teras Wetliny jest podobny jak w dolinie górnego Sanu. Tam również terasa wczesnoholoceńska ma złożoną budowę (pokrywa akumulacyjna z późnego glacjału i starszego holocenu), dominuje powierzchniowo i na niej znajdują się prawie wszystkie torfowiska wysokie (Ralska-Jasiewiczowa 1969, 1980, Haczewski i in. 1998). Analogicznie jest w dolinie Wołosatki-Wołosatego (bieszczadzki dopływ Sanu) (Pękala 1966, Pękala i in. 1972, Tokarski 1975, Haczewski i in. 2001). Podobne wątpliwości budzi wiek wyższych teras Sanu i Wołosatki z uwagi na możliwość ich dwudzielności odpowiadającej któremuś z glacjałów plejstocenu (Gerlach i in. 1997, Starkel 1997, 2003, 2014). W dolinie Wetliny spłaszczenia najwyższego poziomu (ok. $60 \mathrm{~m}$ ) wraz z zachowanymi na nich resztkami żwirów nawiązują hipsometrycznie i wiekowo do spłaszczenia o wysokości 100 m nad Sanem koło miejscowości Rajskie i Chmiel. Tam również znajdują się residua najstarszych pokryw żwirowych (Starkel 1965). Pozostałościom wysokiego zasypania doliny Wołosatki (terasy 16-30 m i 11-15 m) K. Pękala (1966) i A. Henkiel (1972) przypisali typ glacis. Szukając podobieństwa cech tego poziomu z doliny Wołosatki z terasami u podnóża Połoniny Wetlińskiej w Wetlinie (20-30 m, 12-15 m) trudno jednak doszukać się analogii i przypisać im taką samą nazwę genetyczną.

Zasadnicza różnica pomiędzy terasami Sanu i Wołosatki z terasami Wetliny tkwi w wyraźnej różnicy ich wysokości. Terasy w dolinie Wetliny są znacznie wyższe, pomimo że rzeka jest zdecydowanie mniejsza od Sanu. Wyższe są wszystkie terasy Wetliny i Górnej Solinki niż wzdłuż Sanu. Mają one podobne, a w wielu miejscach nawet bardziej miąższe pokrywy aluwialne, ale wyższe są ich skalne cokoły. W budowie pokryw plejstoceńskich teras Wetliny zwraca uwagę większy udział piaszczystych glin, w których upakowane są otoczaki, niż w terasach Sanu. Stopień zwietrzenia żwirów w terasach obu dolin wydaje się być podobny. Być może przyczyny wskazanych różnic można doszukiwać się w większej szerokości doliny Sanu i bardziej odpornego podłoża tej doliny.

\section{Rola budowy geologicznej podłoża w formowaniu się teras Wetlinki}

Rozciągłość dna i zboczy doliny Wetliny (oraz Wetlinki) W strefie przeddukielskiej płaszczowiny śląskiej potencjalnie sprzyja dużej dynamice i zróżnicowaniu przestrzennemu procesów rzeźbotwórczych. Już samo założenie i uformowanie się głębokiego obniżenia śród- 
bieszczadzkiego w strefie przeddukielskiej wskazuje na większą podatność utworów tej strefy na procesy denudacyjne i erozję niż w obszarach przyległych: płaszczowinie dukielskiej (grzbiety pasma granicznego od NE) i zdecydowanie piaskowcowych utworach płaszczowiny śląskiej (grzbiet Połoniny Wetlińskiej - Smereka).

Procesom rzeźbotwórczym sprzyja zarówno litologia tej strefy, jak również jej warunki tektoniczne. Składa się ona bowiem z silnie zaburzonych, porozcinanych uskokami i stłoczonych warstw eocenu i oligocenu (Haczewski $\mathrm{i}$ in. 2007). W brzegach i korycie Wetliny odsłaniają się liczne nieciągłości skalnego podłoża, jednak w większości są one wypełnione wtórnie mineralizacją węglanową, co na ogół nie ułatwia procesom erozyjnym rozcinania tego podłoża. Także silne stłoczenie warstw przejawia się ich większą masywnością, co również nie sprzyja destrukcji tych warstw. Korzystną cechą dla procesów niszczących jest natomiast silna fragmentaryzacja tektoniczna podłoża (łuskowa), częsta zmienność litologii i położenia warstw. Dlatego w korycie Wetliny są widoczne na krótkich odcinkach zmiany kierunku upadu warstw, ich rozciągłości, miąższości i rodzaju skał fliszowych. To one sprzyjają lokalnie ześlizgowej pozycji koryta, miejscami wręcz wymuszają jego położenie i decydują o kierunkach skrętów rzeki. Jest również istotne, że bieg doliny Wetliny jest subsekwentny w stosunku do struktur podłoża.

Dynamikę procesów fluwialnych w strefie przeddukielskiej bardziej potęgują jednak litologiczne warunki podłoża. Dominują przestrzennie w tej strefie cienkoławicowe piaskowcowe i piaszczyste mułowce z łupkami szarymi (oddział podotrycki warstw krośnieńskich dolnych) oraz łupki szare i piaskowce cienkoławicowe przewarstwione łupkami czarnymi (z wirowcami i dolomitami żelazistymi) (warstwy przejściowe). Ich lokalnym uzupełnieniem są czarne łupki z cienkoławicowymi piaskowcami i rogowcami (warstwy menilitowe) oraz piaskowce z łupkami marglistymi (warstwy hieroglifowe) (Haczewski $\mathrm{i}$ in. 2001, 2007). W całości tworzą one mozaikę silnie zdeformowanych skał głównie łupkowych i cienkoławicowych, względnie mało odpornych na procesy erozyjne i denudację (Ślączka 1971, Górka, Kuśmierek 1973, Haczewski i in. 2001). W takich warunkach podłoża przebieg procesów rzeźbotwórczych i wietrzeniowych postępuje względnie szybko (ryc. 11).

Strefa przeddukielska ma w miejscowości Wetlina prawie $2 \mathrm{~km}$ szerokości i w jej obrębie są uformowane wszystkie terasy rzeczne. Zatem cokoły teras i dzisiejsze koryto rzeki były wycinane w utworach względnie mało odpornych. Mogły więc w takim podłożu formować się terasy z wysokimi cokołami, a koryto migrować w dnie doliny nawiązując kierunkowo do położenia warstw (ich biegu, kąta i kierunku upadu) i preferując ich podatność na erozję. Przyjmując nawet mniejsze przepływy Wetliny niż pobliskiego Sanu efekt morfologiczny w postaci głębszego rozcinania i tworzenia wyższych teras mógł się zaznaczyć. Nie bez znaczenia dla powstania tego efektu był

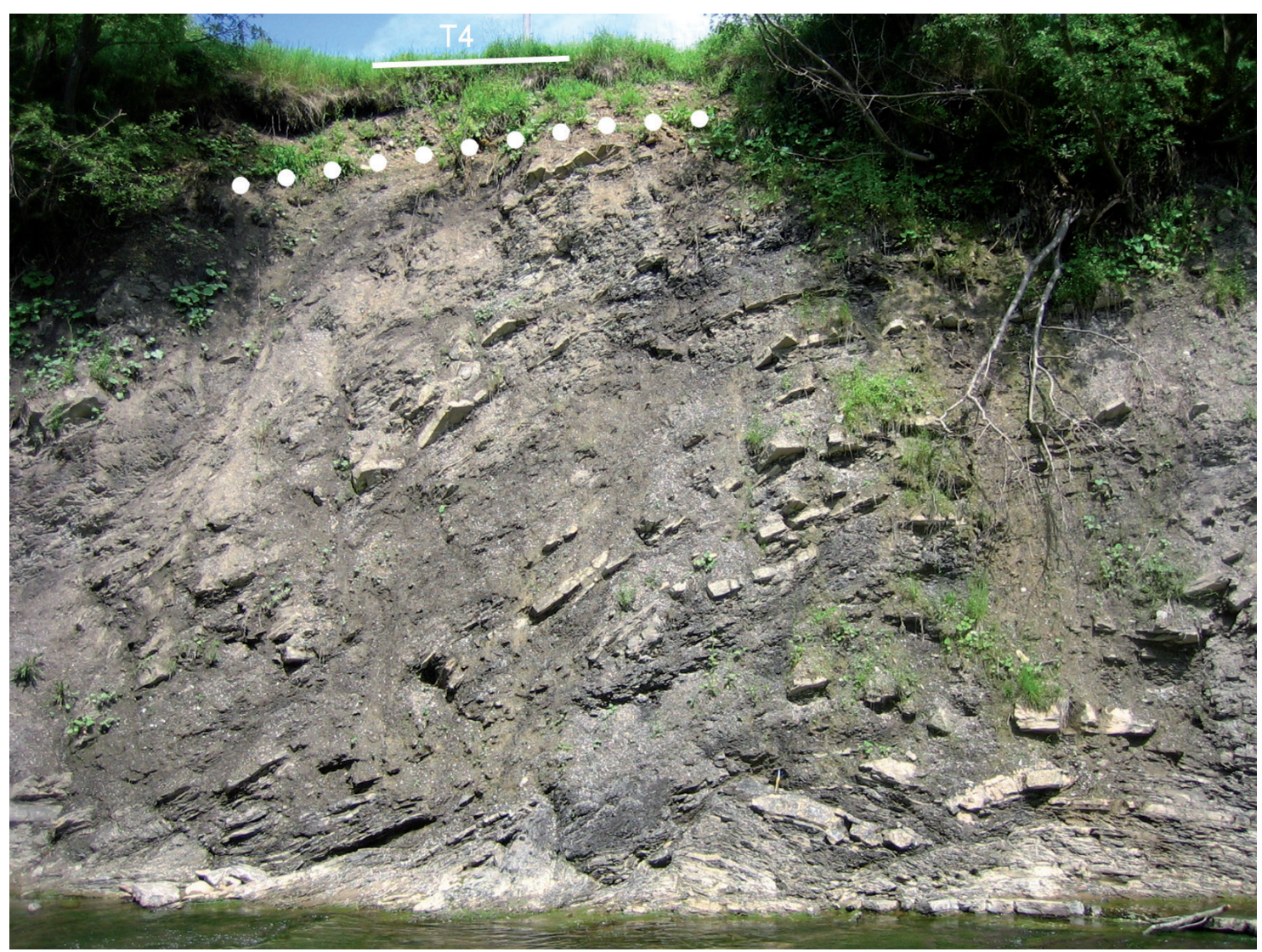

Ryc. 11. Sfałdowane łupki i cienkoławicowe piaskowce w cokole terasy $10 \mathrm{~m}$ (T4) Wetliny (fot. K. Bąk)

Fig. 11. Folded shales and thin-bedded sandstones in the $10 \mathrm{~m}$ terrace (T4) of Wetlina River (Photo: K. Bąk) 
także 3-krotnie większy spadek podłużny Wetliny (16\% - średnio dla całej Wetliny) niż Sanu (5,4\%o). Spadek podłużny Górnej Solinki jest jeszcze większy (21,3\%), a terasy $\mathrm{w}$ tej dolinie są najwyższe $\mathrm{w}$ odcinku II, wyciętym w średnio odpornych warstwach hieroglifowych (łupki, piaskowce cienko- i średnioławicowe oraz margle) jednostki dukielskiej. Rzeka przełamując się w odcinku IV przez bardzo odporne pakiety piaskowców warstw ciśniańskich tej jednostki nie wytworzyła już wyraźnych teras, przynajmniej tak szerokich aby mogły się zachować do dziś.

\section{Wnioski}

W dolinie Wetliny jest uformowany pełny zespół czwartorzędowych teras rzecznych obejmujący terasy wysokie (T1, T2). średnie (T3, T4) i niskie (T5, T6). Łącznie w tej dolinie występuje sześć stopni terasowych. Sięgają one daleko w górę dolin źródłowych (Wetlinki, Górnej Solinki). Stopień zachowania teras maleje adekwatnie do ich wieku. Z badań tych teras wynika, że:

1. Każda $\mathrm{z}$ nich posiada własny cokół skalny i w różnym stopniu zachowaną pokrywę aluwiów. Są zatem terasami skalisto-osadowymi (Klimaszewski 1978). Terasy najwyższe mają częściowo zredukowaną pokrywę żwirową lub są przykryte warstwą gliniastogruzowych osadów stokowych.

2. Najobszerniej zespół teras wykształcił się i zachował się w dolinie Wetliny (odcinek C) - poniżej ujścia Górnej Solinki, gdzie dolina jest najszersza i terasy są najwyższe.

3. Terasy Wetliny mają wysokie skalne cokoły, a na odcinku C miąższa jest także ich pokrywa żwirowa, zwłaszcza w terasach $\mathrm{z}$ glacjału środkowopolskiego (T2) i północnopolskiego (T3).

4. Bezpośrednią przyczyną aktualnej krętości rzeki nie jest lokalna zmienność jej spadku podłużnego, bowiem najwyższe wartości wskaźnika rozwinięcia rzeki nie nawiązują przestrzennie do odcinków o małym spadku podłużnym koryta. Krętość rzeki w większym stopniu jest wymuszona położeniem i odpornością skalnego podłoża na erozję rzeczną.

5. Schodowy zespół teras Wetliny jest podobny pod względem budowy i wieku do teras wzdłuż górnego Sanu, ale terasy Wetliny są znacznie wyższe.

6. Duża wysokość teras Wetliny wynika głównie z uwarunkowań geologicznych podłoża doliny (mała odporność utworów strefy przedukielskiej i jej silna fragmentaryzacja tektoniczna).

7. Lokalne wahania wysokości teras niskich nawiązują przestrzennie do odcinków wahań spadku podłużnego koryta w obu dolinach źródłowych i w Wetlinie. Zwiększają wysokość wszystkie terasy na progowych odcinkach koryt, natomiast na odcinkach wyraźnego złagodnienia spadku wysokość teras niskich się zmniejsza.
Identyfikacja zasięgu wysokościowego pokryw żwirowych w terasach wysokich jest w wielu miejscach dyskusyjna. Są one bądź to przykryte deluwiami lub grawitacyjnie redeponowane, albo erozyjnie rozcięte. Długotrwałe zaleganie żwirów na zboczach doliny sprzyjało ich dużemu zwietrzeniu, dlatego zostały one zubożone o składniki mniej odporne lub zachowały się tylko szczątkowo (jak na poziomie ok. $60 \mathrm{~m}$ ). Pokrywy aluwialne teras holoceńskich są zachowane w niezmienionej formie i mają pełny zapis ich przyrostu pionowego od facji korytowej w części spągowej do pozakorytowej (starorzecznej lub terasowej) z rozwijającymi się niskimi torfowiskami w części stropowej.

\section{Podziękowanie}

Opracowanie wykonano $\mathrm{w}$ ramach działalności statutowej tematu realizowanego w latach 2008-2010 w Zakładzie Geografii Fizycznej Instytutu Geografii Uniwersytetu Pedagogicznego im. Komisji Edukacji Narodowej w Krakowie. Autor dziękuje Grzegorzowi Haczewskiemu i Krzysztofowi Bąkowi za udostępnienie fotografii zamieszczonych w tej pracy.

\section{Literatura}

Baumgart-Kotarba M., 1978. Zróznicowanie ruchów tektonicznych w świetle analizy czwartorzędowych teras doliny Białki tatrzańskiej. Studia Geomorphologica Carpatho-Balcanica 12: 93-110.

Baumgart-Kotarba, M., 1983. Kształtowanie koryt i teras rzecznych w warunkach zróżnicowanych ruchów tektonicznych (na przykładzie wschodniego Podhala). Prace Geograficzne IGiPZ PAN 145: 1-133.

Baumgart-Kotarba M., 1991-1992. The geomorphological evolution of the intramontane Orawa Basin associated with neotectonic movements (Polish Carpathians). Studia Geomorphologica Carpatho-Balcanica 25/26: 3-28.

Bogaart P.W., van Balen R.T., 2000. Numerical modeling of the response of alluvial rivers to Quaternary climate change. Global and Planetary Change 27: 147-163.

Dziewański J., Starkel L., 1961. Geneza i wiek terasy wysokiej w dolinie Sanu. Rocznika Polskiego Towarzystwa Geologicznego 31(2-4): 461-467.

Dziewański J., Starkel L., 1962. Dolina Sanu między Soliną a Zwierzyniem w czwartorzędzie. Prace Geograficzne IG PAN 36: 1-86.

Gerlach T., Starkel L., Szczepanek K., 1997. Sites with organic interglacial deposits in the upper San river basin, Polish Eastern Carpathians. Studia Geomorphologica Carpatho-Balcanica 31: 31-42.

Gębica P., Budek A., Starkel L., Jacyszyn A., Krąpiec M., 2008. Nowe wyniki badań nad stratygrafią aluwiów i holoceńską ewolucją doliny Strwiąża (Zachodnia Ukraina). Prace Komisji Paleogeograficznej Czwartorzędu PAU, 6: 93-103.

Górka A., Kuśmierek J., 1973. Tektonika południowych stoków Połoniny Wetlińskiej na tle topograficznych pomiarów i obserwacji geomorfologicznych. Kwartalnik AGH Geologia 17: 147-156.

Haczewski G., Bąk K., Kukulak J., 1998. Objaśnienia do Szczegółowej Mapy Geologicznej Polski 1:50 000. Arkusz Dźwiniacz Górny (1069). Archiwum Państwowego Instytutu Geologicznego, Warszawa - Kraków.

Haczewski G., Bąk K., Kukulak J., Mastella L., Rubinkiewicz J., 2001. Objaśnienia do Szczegółowej Mapy Geologicznej Polski 1:50 000. Arkusz Ustrzyki Górne (1068). Archiwum Państwowego Instytutu Geologicznego, Warszawa - Kraków. 
Haczewski G., Kukulak J., Bąk K. 2007. Budowa geologiczna i rzeźba Bieszczadzkiego Parku Narodowego. Prace Monograficzne 468. Wydawnictwo Naukowe Akademii Pedagogicznej, Kraków: 1-154.

Hancock G.S., Anderson R.S., 2002. Numerical modeling of the fluvial strath-terrace formation in response to oscillating climate. Geological Society of America Bulletin 114(9): 1131-1142.

Henkiel A., 1962. Terasy doliny górnego Strwiąża. Annales UMCS, Sec. B, 17(4): 117-146.

Henkiel A., 1972. Plejstoceńskie spłaszczenia denudacyjne w Karpatach. Annales UMCS, Sec. B, 27: 47-66.

Kaszowski L., Ralska-Jasiewiczowa M., 1972. The Site I-4. Smerek. Excursion Guide-Book Symposium INQUA Commission on Studies of the Holocene, Poland. P. I: 27-30.

Klimaszewski M., 1948. Polskie Karpaty Zachodnie w okresie dyluwialnym. Acta Geographica Univerditatis Vratislaviensis, ser. B 7, 1-233.

Klimaszewski M., 1967. Polskie Karpaty Zachodnie w okresie czwartorzędowym. W: R.Galon, J.Dylik (red.), Czwartorzęd Polski. PWN, Warszawa: 431-497.

Klimaszewski M., 1978. Rzeźba fluwialna. W: Geomorfologia. PWN, Warszawa: 322-406.

Kukulak J., 2004. Zapis skutków osadnictwa i gospodarki rolnej w osadach rzeki górskiej (na przykładzie aluwiów dorzecza górnego Sanu w Bieszczadach Wysokich). Prace Monograficzne381. Wydawnictwo Naukowe Akademii Pedagogicznej, Kraków: 1-125.

Kuśmierek J., 2005. Morfotektonika przełomów Solinki i Wetlinki w świetle badań terenowych i interpretacji zdjęć lotniczych (Bieszczady wysokie). Geologia, 31(2): 225-244.

Kuśmierek J., Magiera J., 1993. Neotektoniczna interpretacja podłużnych profili teras środkowych części dolin Wisłoka i Jasiołki. Folia Quaternaria 64: 137-150.

Lindner L., Nitychoruk J., Butrym J., 1993. Liczba i wiek zlodowaceń tatrzańskich w świetle datowań termoluminescencyjnych osadów wodnolodowcowych w dorzeczu Białego Dunajca. Przegląd Geologiczny 41(1), 10-21.

Magiera J., 1991. Uwagi o wykształceniu, wieku i liczbie teras w dolinie Wisłoki w Obniżeniu Krośnieńskim. Sprawozdania z Posiedzeń Komisji Nauk PAN, Oddz. Kraków: 33(1): 385-387.

Malarz R., 2001. Tempo abrazji żwirów w rzekach karpackich, Sympozjum: Pokrywy stokowe jako zapis zmian klimatycznych w późnym vistulianie i holocenie, Sosnowiec 5-7.04.2001: 39-42.

Malarz R., 2007. Dynamika procesów rzeźbotwórczych we Wschodnich Karpatach fliszowych (na przykładzie dorzecza Wetlinki w Bieszczadach). Konferencja Naukowa: Potencjał ekonomiczny regionów na pograniczu polsko-ukraińskim, Jarosław 11-12.10.2007: 103-112.

Olszak J., 2011. Evolution of fluvial terraces in response to climate change and tectonic uplift during the Pleistocene: evidence from Kamienica and Ochotnica River valleys (Polish Outer Carpathians). Geomorphology 129: 71-78.

Pękala K., 1966. Wpływ lokalnych podstaw erozyjnych na kształtowanie systemu teras (na przykładzie Wołosatego). Annales UMCS, sec. B, 21: 185-219.

Pękala K., 1973. Budowa i rozwój średniej terasy Sanu w Babicach. Annales UMCS, sec. B, 28(4): 71-91.

Pękala K., 1997. Rzeźba Bieszczadzkiego Parku Narodowego. Roczniki Bieszczadzkie, Ustrzyki Dolne, 6: 19-38.

Pękala K., Ralska-Jasiewiczowa M., Starkel L., 1972. The Western Bieszczady Mts. Excursion Guide-Book. Symposium INQUA Commission on Studies of the Holocene. Poland. P. I: 13-23.

Ralska-Jasiewiczowa M., 1969. Ślady kultury człowieka w diagramach pyłkowych z Bieszczadów Zachodnich. Acta Archaeologica Carpathica 11(1): 105-109.
Ralska-Jasiewiczowa M., 1980. Late Glacial and Holocene vegetation of the Bieszczady Mts (Polish Eastern Carpathians). Acta Paleobotanica 20: $202 \mathrm{pp}$.

Sobiecki K., 2000. Wykształcenie holoceńskich poziomów terasowych w dorzeczu górnej Wisłoki. Prace Geograficzne IG UJ 105: 299-318.

Starkel L., 1965. Rozwój rzeźby polskiej części Karpat Wschodnich. Prace Geograficzne IG PAN 50: 1-157.

Starkel L., 1966. Evolution of the relief of the Polish East Carpathians in the Quaternary with the upper San basin as example). Geomorphological problems of the Carpathians. Geographia Polonica 10: 89-114.

Starkel L., 1994. Reflection of the glacial-interglacjal cycle in the evolution of the Vistula river basin, Poland. Terra Nova 6: 1-9.

Starkel L., 1995. Evolution of the Carpathian valleys and the Forecarpathian basins in the Vistulian and Holocene. Studia Geomorphologica Carpatho-Balcanica 29: 5-40.

Starkel L., 1997. The evolution of fluvial systems in the Upper Vistulian and Holocene in the territory of Poland. Landform Analysis 1: 7-18.

Starkel L., 2003. Climatically controlled terrases in uplifting mountains areas. Quaternary Science Reviews 22: 2189-2198.

Starkel L., 2014. O niektórych prawidłowościach rozwoju rzeźby gór i ich przedpoli. IGiPZ PAN. Wydawnictwo Akademickie Sedno: $1-318$.

Starkel L., Gębica P., Kalicki T., Ludwikowska M., Niedziałkowska E., 1999. Chronostratygrafia aluwiów i form fluwialnych w południowej Polsce (w:) A.Pazdur, A.Bluszcz, W.Stankowski, L.Starkel (red.). Geochronologia górnego czwartorzędu Polski: 133-155.

Starkel L., Gębica, P., Superson, J., 2007. Last Glacial-Interglacial cycle in the evolution of river valleys in southern and central Poland. Quaternary Science Reviews 26, 2924-2936

Stupnicka E., Szumański T., 1957. Dwudzielność młodoplejstoceńskich poziomów żwirowych w Karpatach. Acta Geologica Polonica 7(4): 439-446.

Ślączka A., 1971. Geologia jednostki dukielskiej. Prace Instytutu Geologicznego 63: 1-97.

Ślączka A., Żytko K., 1978. Szczegółowa Mapa geologiczna Polski ark. Łupków. Instytut Geologiczny, Warszawa.

Tokarski A., 1975. Geologia i geomorfologia okolic Ustrzyk Górnych (polskie Karpaty Wschodnie). Studia Geologica Polonica 48: 1-90.

Vandenberghe J., 2002. The relation between climate and river processes, landforms and deposits during the Quaternary. Quaternary International 91: 17-23.

Wójcik A., 1988. Systemy teras rzecznych dorzecza Koszarawy w Beskidzie Żywieckim i ich związek z ruchami tektonicznymi. Studia Geomorph. Carp.-Balc. 22. Kraków:21-43

Wójcik A., 1997. Lateglacial deposits in the Ropa valley floor in Wysowa, Beskid Niski Mts, Carpathians. Studia Geomorphologica Carpatho-Balcanica 31: 101-109.

Wójcik A., 2003. Czwartorzęd zachodniej części Dołów Jasielsko-Sanockich (polskie Karpaty Zewnętrzne). Prace Państwowego Instytutu Geologicznego 178: 1-148.

Ziętara T., 1972. Rzeźba beskidzkiej części dorzecza Soły. Czasopismo Geograficzne 43(2): 151-169.

Zuchiewicz W., 1984. The Late Neogene-Quaternary tectonic mobility of the Polish West Carpathians. A case study of the Dunajec drainage basin. Roczniki Polskiego Towarzystwa Geologicznego 54: 133-189.

Zuchiewicz W., 1987. Evolution of the Beskid Niski Mts. and morphotectonics of the Polish Carpathians. Zeszyty Naukowe AGH, Geologia 13(3-4): 3-167.

Zuchiewicz W., 1992. Pozycja stratygraficzna tarasów Dunajca w Karpatach Zachodnich. Przegląd Geologiczny 40(7): 436-445. 